\title{
Do land surface models need to include differential plant species responses to drought? Examining model predictions across a mesic-xeric gradient in Europe
}

\author{
M. G. De Kauwe ${ }^{1}$, S.-X. Zhou ${ }^{1,2}$, B. E. Medlyn ${ }^{1,3}$, A. J. Pitman ${ }^{4}$, Y.-P. Wang ${ }^{5}$, R. A. Duursma ${ }^{3}$, and I. C. Prentice ${ }^{1,6}$ \\ ${ }^{1}$ Macquarie University, Department of Biological Sciences, New South Wales 2109, Australia \\ ${ }^{2}$ CSIRO Agriculture Flagship, Waite Campus, PMB 2, Glen Osmond, SA 5064, Australia \\ ${ }^{3}$ Hawkesbury Institute for the Environment, Western Sydney University, Locked Bag 1797, Penrith, NSW, Australia \\ ${ }^{4}$ Australian Research Council Centre of Excellence for Climate Systems Science and Climate Change Research Centre, \\ UNSW, Sydney, Austraila \\ ${ }^{5}$ CSIRO Ocean and Atmosphere Flagship, Private Bag \#1, Aspendale, Victoria 3195, Australia \\ ${ }^{6}$ AXA Chair of Biosphere and Climate Impacts, Grand Challenges in Ecosystems and the Environment and Grantham \\ Institute - Climate Change and the Environment, Department of Life Sciences, Imperial College London, Silwood Park \\ Campus, Buckhurst Road, Ascot SL5 7PY, UK
}

Correspondence to: M. G. De Kauwe (mdekauwe@gmail.com)

Received: 16 July 2015 - Published in Biogeosciences Discuss.: 6 August 2015

Revised: 7 December 2015 - Accepted: 11 December 2015 - Published: 21 December 2015

\begin{abstract}
Future climate change has the potential to increase drought in many regions of the globe, making it essential that land surface models (LSMs) used in coupled climate models realistically capture the drought responses of vegetation. Recent data syntheses show that drought sensitivity varies considerably among plants from different climate zones, but state-of-the-art LSMs currently assume the same drought sensitivity for all vegetation. We tested whether variable drought sensitivities are needed to explain the observed large-scale patterns of drought impact on the carbon, water and energy fluxes. We implemented data-driven drought sensitivities in the Community Atmosphere Biosphere Land Exchange (CABLE) LSM and evaluated alternative sensitivities across a latitudinal gradient in Europe during the 2003 heatwave. The model predicted an overly abrupt onset of drought unless average soil water potential was calculated with dynamic weighting across soil layers. We found that high drought sensitivity at the most mesic sites, and low drought sensitivity at the most xeric sites, was necessary to accurately model responses during drought. Our results indicate that LSMs will over-estimate drought impacts in drier climates unless different sensitivity of vegetation to drought is taken into account.
\end{abstract}

\section{Introduction}

Changes in regional precipitation patterns with climate change are highly uncertain (Sillmann et al., 2014), but are widely expected to result in a change in the frequency, duration and severity of drought events (Allen et al., 2010). Drought is broadly defined, but for plants is a marked deficit of moisture in the root zone which results from a period of low rainfall and/or increased atmospheric demand for evapotranspiration. Recently, a series of high-profile drought events (Ciais et al., 2005; Fensham et al., 2009; Phillips et al., 2009; Lewis et al., 2011) and associated tree mortality (Breshears et al., 2005; van Mantgem et al., 2009; Peng et al., 2011; Anderegg et al., 2013), have occurred across the globe and these events have led to debate as to whether incidences of drought are increasing (Allen et al., 2010; Dai et al., 2013, but see Sheffield et al., 2012). Drought and any ensuing vegetation mortality events have the potential to change land ecosystems from a sink to source (Lewis et al., 2011), and the dominant mechanisms governing the ecosystem responses to drought can vary from reducing stomatal conductance $(\mathrm{Xu}$ and Baldocchi, 2003) to increasing tree mortality (Lewis et al., 2011) and changing community species composition (Nepstad et al., 2007). 
Our ability to model drought effect on vegetation function (carbon and water fluxes) is currently limited (Galbraith et al., 2010; Egea et al., 2011; Powell et al., 2013). Remarkably, given the importance of correctly capturing drought impacts on carbon and water fluxes, land surface models (LSMs) designed for use in climate models have rarely been benchmarked against extreme drought events. Mahfouf et al. (1996) compared summertime crop transpiration from 14 land surface schemes, finding that only half of the models fell within the uncertainty range of the observations. They attributed differences among models to the various schemes used by models to represent transpiration processes (e.g. soil water stress function, different number of soil layers) and variability in the initial soil water content at the start of the growing season which relates to variability in the way bare soil evaporation and drainage are represented among different models. Galbraith et al. (2010) showed that a set of dynamic global vegetation models (DGVMs) were unable to capture the $20-30 \%$ reduction in biomass due to drought during a set of throughfall exclusion experiments in the Amazon. Galbraith et al. (2010) attributed model variability during drought to changes in autotrophic respiration (which was not supported by the data), model insensitivity to observed leaf area reductions, and the use of different empirical functions to down-regulate productivity during water stress. The models differed both in terms of timescale of the application of this function (sub-diurnal vs. daily) and whether it was used to down-regulate net photosynthesis or the maximum rate of Rubisco activity, $V_{\text {cmax }}$. Similarly, Powell et al. (2013) demonstrated that a group of five models were unable to predict drought-induced reductions in aboveground biomass $(\sim 20 \%)$ in two large-scale Amazon experiments. Gerten et al. (2008) compared the effect of adjusting precipitation regimes on simulated net primary productivity (NPP) by four ecosystem models across a range of hydroclimates. They found a consistent direction of change (in terms of NPP) with different scenarios across models but found that the seasonal evolution of soil moisture differed among the models.

In order for models to better capture realistic responses during drought, they need to draw more closely on experimental data (see Chaves et al., 2003 for a review). One key observation is that there is a continuum of species responses to soil moisture deficit, ranging from isohydric (stomata close rapidly during drought, maintaining a minimum leaf water potential, $\Psi_{1}$ ) to anisohydric (stomata remain open during drought, which allows $\Psi_{1}$ to decrease) hydraulic strategies (Tardieu and Simonneau, 1998; Klein, 2014). These differences are widely observed and are thought to be important in determining resilience to drought (McDowell et al., 2008; Mitchell et al., 2013; Garcia-Forner et al., 2015). Many traits, including hydraulic conductivity, resistance to cavitation, turgor loss point, stomatal regulation and rooting depth, contribute to these differences. Systematic differences in the response of leaf gas exchange to soil moisture potential have been observed among species originating from different hydroclimates (Zhou et al., 2013), with species from mesic environments showing stronger stomatal sensitivity to drought than species from xeric environments. Currently, these environmental gradients in species behaviour are not captured in LSMs, which typically assume static plant functional type (PFT) parameterisations. This is in part because historically the data required to describe these attributes have not been available at the global scale, but also due to the necessity of simplification required to run global climate model simulations. Species with a PFT are assumed to have similar or identical sensitivities to drought. Such an approach ignores experimental evidence of the range of sensitivities to drought among species (Choat et al., 2012; Limousin et al., 2013; Zhou et al., 2014; Mitchell et al., 2014; Mencuccini et al., 2015). For example, Turner et al. (1984) found contrasting responses in leaf water potential to increasing vapour pressure deficit, ranging from isohydric to anisohydric, among a group of woody and herbaceous species. Similarly, Zhou et al. (2014) found that in a dry-down experiment, European sapling species originating from more mesic environments were more sensitive to water stress (more rapid reduction of photosynthesis and stomatal conductance) than species from more xeric regions. However, it is not known whether observed differences in the response to soil moisture deficit among species are important in determining fluxes at large scales.

In this study we test whether differences in species' responses to drought are needed to capture drought responses on a continental scale. We built on recent changes to the stomatal conductance $\left(g_{\mathrm{s}}\right)$ scheme (De Kauwe et al., 2015) within the Community Atmosphere Biosphere Land Exchange (CABLE) LSM (Wang et al., 2011), by implementing a new formulation for drought impacts based on plant ecophysiological studies for 31 species (Zhou et al., 2013, 2014). We obtained three parameterisations for drought response from these studies, characterising low, medium and high sensitivities to drought. We then applied CABLE to simulate responses to an extreme meteorological event, the European 2003 heatwave, at five eddy covariance sites covering a latitudinal gradient, transitioning from mesic sites at the northern extreme to xeric at the southern sites. Observations show that there was a significant impact of drought on ecosystem fluxes at these sites (Ciais et al., 2005; Schär et al., 2004). We note that models have been applied to simulate drought effects on productivity (net primary production) and leaf area at individual sites (Ciais et al., 2005; Fischer et al., 2007; Granier et al., 2007; Reichstein et al., 2007) but have not been used to examine whether alternative parameterisations are needed to capture drought responses across sites. We therefore tested how well CABLE was able to simulate the impact of drought on carbon and water fluxes at these sites using alternative parameterisations for drought sensitivity. We hypothesised that drought sensitivity would increase as sites transitioned from xeric to mesic. We hypothesised 
that trees at more mesic sites, with a greater abundance of available water than at xeric sites, would be more vulnerable to shorter duration droughts, and thus have higher drought sensitivity (or lower resistance to drought). Therefore, accounting for this latitudinal gradient in drought sensitivity would improve the performance of CABLE.

\section{Methods}

\subsection{Model description}

CABLE represents the vegetation using a single layer, twoleaf canopy model separated into sunlit and shaded leaves (Wang and Leuning, 1998), with a detailed treatment of within-canopy turbulence (Raupach, 1994; Raupach et al., 1997). Soil water and heat conduction is numerically integrated over six discrete soil layers following the Richards equation and up to three layers of snow can accumulate on the soil surface. A complete description can be found in Kowalczyk et al. (2006) and Wang et al. (2011). CABLE has been used extensively for both offline (Abramowitz et al., 2008; Wang et al., 2011; De Kauwe et al., 2015) and coupled simulations (Cruz et al., 2010; Pitman et al., 2011; Mao et al., 2011; Lorenz et al., 2014) within the Australian Community Climate Earth System Simulator (ACCESS, see http://www.accessimulator.org.au; Kowalczyk et al., 2013); a fully coupled earth system model. The source code can be accessed after registration at https://trac.nci.org.au/trac/cable.

\subsection{Representing drought stress within CABLE}

We build on the work by De Kauwe et al. (2015), who introduced a new $g_{\mathrm{s}}$ scheme into CABLE. In this scheme, stomata are assumed to behave optimally; that is, stomata are regulated to maximise carbon gain whilst simultaneously minimising water loss, over short time periods (i.e. a day) (Cowan and Farquhar, 1977) leading to the following formulation of $g_{\mathrm{s}}$ (Medlyn et al., 2011):

$g_{\mathrm{s}}=g_{0}+1.6\left(1+\frac{g_{1}}{\sqrt{D}}\right) \frac{A}{C_{\mathrm{s}}}$,

where $A$ is the net assimilation rate $\left(\mu \mathrm{mol} \mathrm{m}^{-2} \mathrm{~s}^{-1}\right), C_{\mathrm{s}}$ $\left(\mu \mathrm{mol} \mathrm{mol}^{-1}\right)$ and $D(\mathrm{kPa})$ are the $\mathrm{CO}_{2}$ concentration and the vapour pressure deficit at the leaf surface, respectively, and $g_{0}\left(\mathrm{~mol} \mathrm{~m}^{-2} \mathrm{~s}^{-1}\right)$ and $g_{1}$ are fitted constants representing the residual stomatal conductance when $A$ reaches zero, and the slope of the sensitivity of $g_{\mathrm{s}}$ to $A$, respectively. The model was parameterised for different PFTs using data from Lin et al. (2015) (see De Kauwe et al., 2015).

In the standard version of CABLE, drought stress is implemented as an empirical scalar $(\beta)$ that depends on soil moisture content, weighted by the fraction of roots in each of
CABLE's six soil layers:

$\beta=\sum_{i=1}^{n} f_{\mathrm{root}, i} \frac{\theta_{i}-\theta_{w}}{\theta_{\mathrm{fc}}-\theta_{w}} ; \beta \in[0,1]$,

where $\theta_{i}$ is the volumetric soil moisture content $\left(\mathrm{m}^{3} \mathrm{~m}^{-3}\right)$ in soil layer $i, \theta_{\mathrm{w}}$ is the wilting point $\left(\mathrm{m}^{3} \mathrm{~m}^{-3}\right), \theta_{\mathrm{fc}}$ is the field capacity $\left(\mathrm{m}^{3} \mathrm{~m}^{-3}\right)$ and $f_{\text {root }, i}$ is the fraction of root mass in soil layer $i$. The six soil layers in CABLE have depths of $0.022,0.058,0.154,0.409,1.085$ and $2.872 \mathrm{~m}$. The factor $\beta$ is assumed to limit the slope of the relationship between stomatal conductance $\left(g_{\mathrm{s}}, \mathrm{mol} \mathrm{m}^{-2} \mathrm{~s}^{-1}\right.$; Leuning 1995) by acting as a modifier on the parameter $g_{1}$.

In this study, we introduced a new expression for drought sensitivity of gas exchange, based on the work of Zhou et al. $(2013,2014)$. In this model, both $g_{1}$ and the photosynthetic parameters $V_{\text {cmax }}$ and $J_{\max }$ are assumed to be sensitive to pre-dawn leaf water potential, but this sensitivity varies across species. There is considerable evidence that both $g_{1}$ and $V_{\text {cmax }}$ are sensitive to soil moisture (Keenan et al., 2009; Egea et al., 2011; Flexas et al., 2012; Zhou et al., 2013). There is also widespread evidence that plants respond more directly to water potential rather than water content (Comstock and Mencuccini, 1998; Verhoef and Egea, 2014).

Zhou et al. (2013) extended the optimal stomatal model of Medlyn et al. (2011) by fitting an exponential function to relate $g_{1}$ to pre-dawn leaf water potential $\left(\Psi_{\mathrm{pd}}\right)$ :

$g_{1}=g_{1 \text { wet }} \times \exp \left(b \Psi_{\mathrm{pd}}\right)$,

where $g_{1 \text { wet }}$ is the fitted parameter representing plant water use under well-watered conditions (i.e. when $\Psi_{\mathrm{pd}}=0$ ) and $b$ is a fitted parameter representing the sensitivity of $g_{1}$ to $\Psi_{\mathrm{pd}}$. Species with different water use strategies can by hypothesised to differ in not only their $g_{1}$ parameter under wellwatered conditions, $g_{1 \text { wet }}$ (see Lin et al., 2015), but also with the sensitivity to $\Psi_{\mathrm{pd}}, b$. Zhou et al. (2013) also advanced a non-stomatal limitation to the photosynthetic biochemistry, which describes the apparent effect of water stress on $V_{\text {cmax }}$ :

$V_{\text {cmax }}=V_{\text {cmax, wet }} \frac{1+\exp \left(S_{\mathrm{f}} \Psi_{\mathrm{f}}\right)}{1+\exp \left(S_{\mathrm{f}}\left(\Psi_{\mathrm{f}}-\Psi_{\mathrm{pd}}\right)\right)}$,

where $V_{\text {cmax,wet }}$ is the $V_{\text {cmax }}$ value in well-watered conditions, $S_{\mathrm{f}}$ is a sensitivity parameter describing the steepness of the decline with water stress, $\Psi_{\mathrm{f}}$ is the water potential at which $\Psi_{\mathrm{pd}}$ decreases to half of its maximum value. As with $g_{1}$, it is hypothesised that in the same way species vary in their $V_{\text {cmax }}$ values in well-watered conditions $\left(V_{\text {cmax,wet }}\right)$, they would also differ in their sensitivity of down-regulated $V_{\text {cmax }}$ with water stress (Zhou et al., 2014). In CABLE, as there is a constant ratio between the parameters $J_{\max }$ and $V_{\text {cmax }}$, the parameter $J_{\max }$ is similarly reduced by drought.

To implement Eq. (6) in CABLE we first had to convert soil moisture content $(\theta)$ to pre-dawn leaf water potential $\left(\Psi_{\mathrm{pd}}\right)$. We did so by assuming that overnight $\Psi_{\mathrm{pd}}$ 
and $\Psi_{\mathrm{S}}$ equilibrate before sunrise, thus ignoring any nighttime transpiration (Dawson et al., 2007). Following Campbell (1974), we related $\theta$ to $\Psi_{\mathrm{S}}$ in each soil layer by

$\Psi_{\mathrm{S}, i}=\Psi_{\mathrm{e}}\left(\frac{\theta_{i}}{\theta_{\mathrm{sat}}}\right)^{-k}$,

where $\Psi_{\mathrm{e}}$ is the air entry water potential (MPa) and $k$ (unitless) is an empirical coefficient which is related to the soil texture. Values for $\Psi_{\mathrm{e}}$ and $b$ are taken from CABLE's standard lookup table following Clapp and Hornberger (1978). We then needed to obtain a representative weighted estimate of $\Psi_{\mathrm{S}}$ across CABLE's soil layers. We tested three potential approaches for weighting in this paper:

i. Using the root-biomass weighted $\theta$ and converting this to $\Psi_{\mathrm{S}}$ using Eq. (8), hereafter denoted M1. Such an approach is often favoured by models, following experimental evidence that plants preferentially access regions in the root zone where water is most freely available (Green and Clotheir, 1995; Huang et al., 1997).

ii. Taking the integrated $\theta$ over the top 5 soil layers $(1.7 \mathrm{~m}$ depth) and converting this to $\Psi_{\mathrm{S}}$ using Eq. (8), hereafter denoted M2. This method assumes the plant effectively has access to an entire "bucket" of soil water. This approach is often favoured by "simpler" forest productivity models (e.g. Landsberg and Waring, 1997).

iii. Weighting the average $\Psi_{\mathrm{S}}$ for each of the six soil layers by the weighted soil-to-root conductance to water uptake of each layer, following Williams et al. (1996, 2001), hereafter denoted M3. The total conductance term depends on the combination of a soil component $\left(R_{\mathrm{S}}\right)$ and a root component $\left(R_{\mathrm{r}}\right) . R_{\mathrm{S}}$ is defined as (Gardner, 1960)

$$
R_{\mathrm{S}}=\frac{\ln \left(\frac{r_{\mathrm{s}}}{r_{\mathrm{r}}}\right)}{2 \pi l_{\mathrm{r}} D G_{\mathrm{soil}}},
$$

where $r_{\mathrm{s}}$ is the mean distance between roots (m), $r_{\mathrm{r}}$ is the fine root radius $(m), D$ is the depth of the soil layer, $G_{\text {soil }}$ is the soil conductivity $\left(\mathrm{mmol} \mathrm{m}{ }^{-1} \mathrm{~s}^{-1} \mathrm{MPa}^{-1}\right.$ ) which depends on soil texture and soil water content, $l_{\mathrm{r}}$ is the fine root density $\left(\mathrm{mm}^{-3}\right) . R_{\mathrm{r}}$ is defined as

$R_{\mathrm{r}}=\frac{R_{\mathrm{r}}^{*}}{F D}$,

where $R_{\mathrm{r}}^{*}$ is the root resistivity ( $\mathrm{MPas} \mathrm{g} \mathrm{mmol}{ }^{-1}$ ), $F$ is the root biomass per unit volume $\left(\mathrm{g} \mathrm{m}^{-3}\right)$. This method weights $\Psi_{\mathrm{S}}$ to the upper soil layers when the soil is wet, but shifts towards lower layers as the soil dries, due to the lower soil hydraulic conductance (e.g. Duursma et al., 2011).
Table 1. Baseline parameter values used to represent the three sensitivities: "high" (Quercus robur), "medium" (Quercus ilex) and "low" (Cedrus atlantica) to drought stress. Parameter values are taken from Zhou et al. (2013, 2014).

\begin{tabular}{lrrr}
\hline Sensitivity & $b$ & $S_{\mathrm{f}}$ & $\Psi_{\mathrm{f}}$ \\
\hline High & 1.55 & 6.0 & -0.53 \\
Medium & 0.82 & 1.9 & -1.85 \\
Low & 0.46 & 5.28 & -2.31 \\
\hline
\end{tabular}

\subsection{Model simulations}

During 2003, Europe experienced an anomalously dry summer, amplified by a combination of a preceding dry spring and high summer temperatures (Ciais et al., 2005; Schär et al., 2004). Summer temperatures were recorded to have exceeded the 30-year June-July-August (JJA) average by $3{ }^{\circ} \mathrm{C}$ (Schär et al., 2004). Consequently we choose to focus our model comparisons on this period, in particular the period between June and September 2003.

At each of the five Fluxnet sites we ran three sets of simulations:

- A control simulation ("CTRL"), representing CABLE version 2.0.1.

- Three simulations to explore the new drought model using a "high" (Quercus robur), "medium" (Quercus ilex) and "low" (Cedrus atlantica) sensitivity to soil moisture. Parameter values were obtained from the metaanalysis by Zhou et al. $(2013,2014)$ and are given in Table 1. For each of these simulations we also tested the three different methods of obtaining $\Psi_{\mathrm{S}}$ as described above.

- A "no drought" simulation in which any transpired water was returned to the soil. By comparing this simulation with either the control or any of the new drought model simulations (high, medium, low), a guide to the magnitude of the drought should be apparent.

Model parameters were not calibrated to match site characteristics; instead default PFT parameters were used for each site. Although CABLE has the ability to simulate full carbon, nitrogen and phosphorus biogeochemical cycling, this feature was not activated for this study, instead only the carbon and water cycle were simulated. For all simulations, leaf area index (LAI) was prescribed using CABLE's gridded monthly LAI climatology derived from Moderate-resolution Imaging Spectroradiometer (MODIS) LAI data (Knyazikhin et al., 1998, 1999) and the $g_{\mathrm{s}}$ scheme following Medlyn et al. (2011; see De Kauwe et al., 2015) was used throughout. All model simulations were spun-up by repeating the meteorological forcing site data until soil moisture and soil temperatures reached equilibrium (as we were ignoring the full biogeochemical cycling in these simulations). 


\subsection{Data sets used}

To assess the performance of the CABLE model both with and without the new drought scheme, we selected a gradient of five forested Fluxnet (http://www.fluxdata.org/) sites across Europe (Table 2) from those available through the Protocol for the Analysis of Land Surface models (PALS; www.pals.unsw.edu.au; Abramowitz, 2012). These data have previously been pre-processed and quality controlled for use within the LSM community. Consequently, all site years had near-complete observations of key meteorological drivers (as opposed to significant gap-filled periods).

Model simulations were compared to measured latent heat and flux-derived gross primary productivity (GPP) at each of the FLUXNET sites. Flux-derived GPP estimates are calculated from the measured net ecosystem exchange (NEE) of carbon between the atmosphere and the vegetation/soil, and the modelled ecosystem respiration $\left(R_{\mathrm{eco}}\right)$, where GPP is calculated as $\mathrm{NEE}+R_{\mathrm{eco}}$.

\section{Results}

\subsection{Severity of the 2003 drought}

Table 3 summarises summer differences in rainfall, air temperature, GPP and LE between 2002 and 2003 across the five sites covering the latitudinal gradient from mesic to xeric sites across Europe. Whilst the impact of the 2003 heatwave varied between sites, every site was warmer and drier in 2003. Similarly, GPP was lower at every site except Espirra, and LE was lower at three of the sites (Hesse, Roccarespampani and Castelporziano) in 2003 than in 2002.

\subsection{Simulated fluxes during drought from the standard model}

Figure 1 shows a site-scale comparison between standard CABLE (CTRL) transpiration ( $E$ ), flux-derived GPP, and the observed LE at the five sites. Tables 4 and 5 show a series of summary statistics (Root Mean Squared Error (RMSE), Nash-Sutcliffe efficiency (NSE), Pearsons's correlation coefficient $(r)$ between modelled and observed GPP and LE. An indication of the severity of the drought can be obtained by comparing the difference between the "No drought" and the CTRL simulation.

For the two more mesic sites (Tharandt and Hesse), the CTRL simulation generally matched the trajectory of the observed LE, but displayed systematic periods of overestimation (i.e. under-estimated the drought effect). By contrast, in the three more xeric sites (Roccarespampani, Castelporziano and Espirra), the reverse was true: the CTRL simulations descended into drought stress much more quickly than the observed fluxes. This rapid drought progression was particularly evident around day of year 155 at the Roccarespampani site. Across all sites, agreement with observed
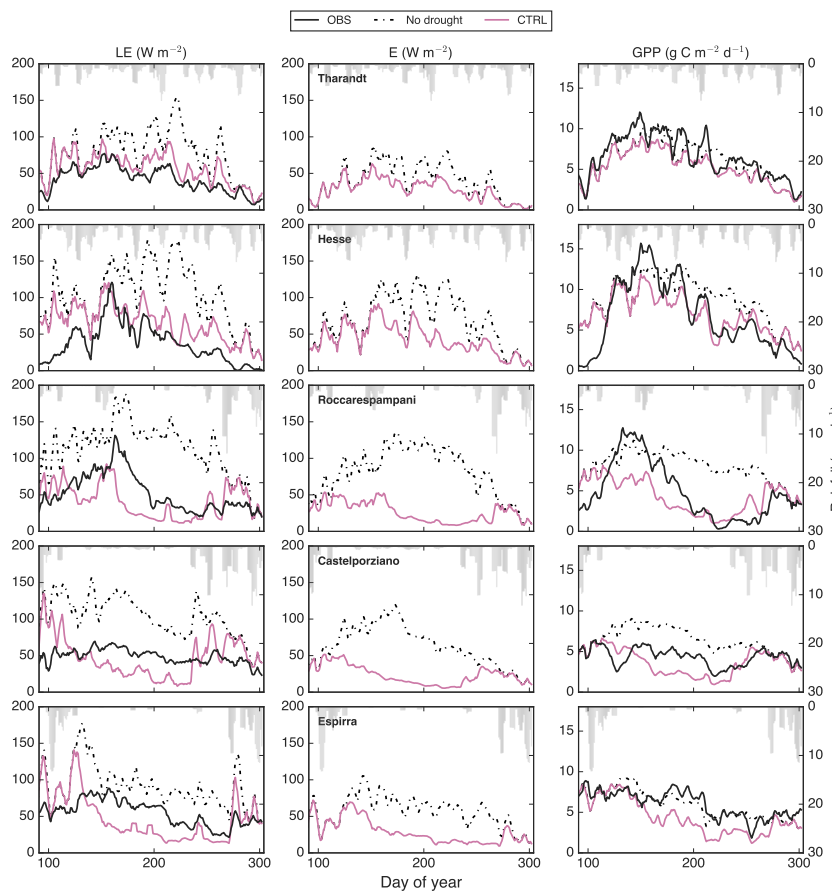

Figure 1. A comparison of the observed (OBS) and modelled (CTRL) Latent Heat (LE) and transpiration $(E)$ at five Fluxnet sites during 2003. The data have been smoothed with a 5-day moving window to aid visualisation.

LE fluxes was generally poor $\left(\mathrm{RMSE}=21.25\right.$ to $38 \mathrm{~W} \mathrm{~m}^{-2}$; $\mathrm{NSE}=-8.95$ to 0.15 ). This outcome is partly a result of the high soil evaporation around mid-spring, which results in CABLE simulating very large LE fluxes during this period.

At Tharandt, Hesse and Roccarespampani, simulated GPP systematically underestimated the flux-derived peak GPP, particularly evident before day of year 180. Transitioning to the more xeric sites (Roccarespampani, Castelporziano and Espirra), simulated GPP was apparently too sensitive to water stress, contributing to a poor agreement with flux-derived data $\left(\mathrm{RMSE}=2.22\right.$ to $3.03 \mathrm{~g} \mathrm{C} \mathrm{m}^{-2}$; $\mathrm{NSE}=-2.67$ to 0.42 ).

\subsection{Theoretical behaviour of new drought scheme}

We now consider the implementation of the new drought model and the three sensitivity parameterisations. Figure $2 \mathrm{a}$ shows how leaf-level photosynthesis is predicted to decline (using Eqs. 3 and 4) in the new drought model with increasing water stress (more negative $\Psi_{\mathrm{S}}$ ). The different sensitivities to drought are clearly visible, with the three parameterisations representing a spectrum of behaviour ranging from high to low drought sensitivity. Figure $2 \mathrm{~b}$ and $\mathrm{c}$ show how the new drought model compares to the standard CABLE (CTRL; using Eq. 2) model on a sandy and clay soil type. The CTRL model is seen to most closely match the high sensitivity simulation on a sandy soil, but it predicts an earlier descent into drought stress. By contrast on the clay soil, the 
Table 2. Summary of flux tower sites.

\begin{tabular}{lllllll}
\hline Site & PFT & Dominant species & Latitude & Longitude & Country & Sand/Silt/Clay Fraction \\
\hline Tharandt & ENF & Picea abies & $50^{\circ} 58^{\prime} \mathrm{N}$ & $13^{\circ} 34^{\prime} \mathrm{E}$ & Germany & $0.37 / 0.33 / 0.3$ \\
Hesse & DBF & Fagus sylvatica & $48^{\circ} 40^{\prime} \mathrm{N}$ & $7^{\circ} 05^{\prime} \mathrm{E}$ & France & $0.37 / 0.33 / 0.3$ \\
Roccarespampani & DBF & Quercus cerris & $42^{\circ} 24^{\prime} \mathrm{N}$ & $11^{\circ} 55^{\prime} \mathrm{E}$ & Italy & $0.6 / 0.2 / 0.2$ \\
Castelporziano & EBF & Quercus ilex & $41^{\circ} 42^{\prime} \mathrm{N}$ & $12^{\circ} 22^{\prime} \mathrm{E}$ & Italy & $0.6 / 0.2 / 0.2$ \\
Espirra & EBF & Eucalyptus globulus & $38^{\circ} 38^{\prime} \mathrm{N}$ & $8^{\circ} 36^{\prime \circ} \mathrm{W}$ & Portugal & $0.37 / 0.33 / 0.3$ \\
\hline
\end{tabular}

Table 3. Mean change in climate and fluxes between 2002 and 2003 covering the period between June and September.

\begin{tabular}{lrrrr}
\hline Site & $\begin{array}{r}\text { Precipitation } \\
\left(\mathrm{mm} \mathrm{month}^{-1}\right)\end{array}$ & $\begin{array}{r}\text { Air temperature } \\
\left({ }^{\circ} \mathrm{C}\right)\end{array}$ & $\begin{array}{r}\text { GPP } \\
\left(\mathrm{g} \mathrm{C} \mathrm{m}^{-2} \mathrm{month}^{-1}\right)\end{array}$ & $\begin{array}{r}\text { LE } \\
\left(\mathrm{W} \mathrm{m}^{-2}\right)\end{array}$ \\
\hline Tharandt & -115.57 & 1.45 & -38.45 & 0.52 \\
Hesse & -49.20 & 2.98 & -123.38 & -11.90 \\
Roccarespampani & -87.36 & 2.18 & -71.94 & -6.17 \\
Castelporziano & -20.31 & 4.57 & -49.73 & -6.47 \\
Espirra & -14.45 & 1.77 & 28.46 & 22.83 \\
\hline
\end{tabular}

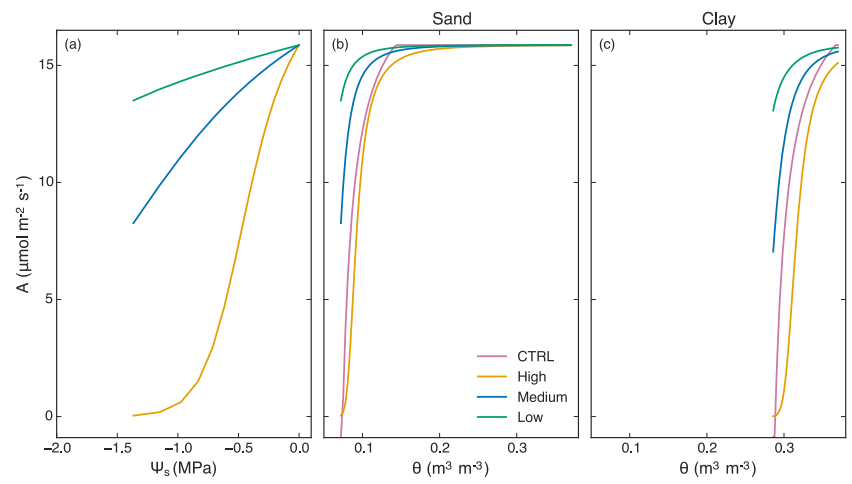

Figure 2. Modelled impact of drought on the assimilation rate $(A)$, shown as (a) a function of volumetric soil moisture content $(\theta)$ and (b) soil water potential $\left(\Psi_{\mathrm{S}}\right)$ for a sand and clay soil.

new medium and high sensitivity simulations encompass the predictions from the CTRL model. The new drought model and parameterisations afford a more flexible sensitivity to the down-regulation of photosynthesis with drought, which is particularly evident in the low sensitivity simulation.

\subsection{Impact of new drought scheme on modelled LE}

Figures 3-7 show the same site comparisons as Fig. 1, but with the addition of the new drought model and the three different ways (M1-3) in which $\Psi_{\mathrm{S}}$ can be averaged over the soil profile. Across all sites it is clear that using M1, the new drought model behaves in much the same way as the CTRL simulation. The explanation is that weighting $\Psi_{\mathrm{S}}$ by the fraction of roots in each layer, results in water being principally extracted from the top three shallow layers (Supplement Figs. S1-S5). Consequently, small changes in $\theta$ result in a

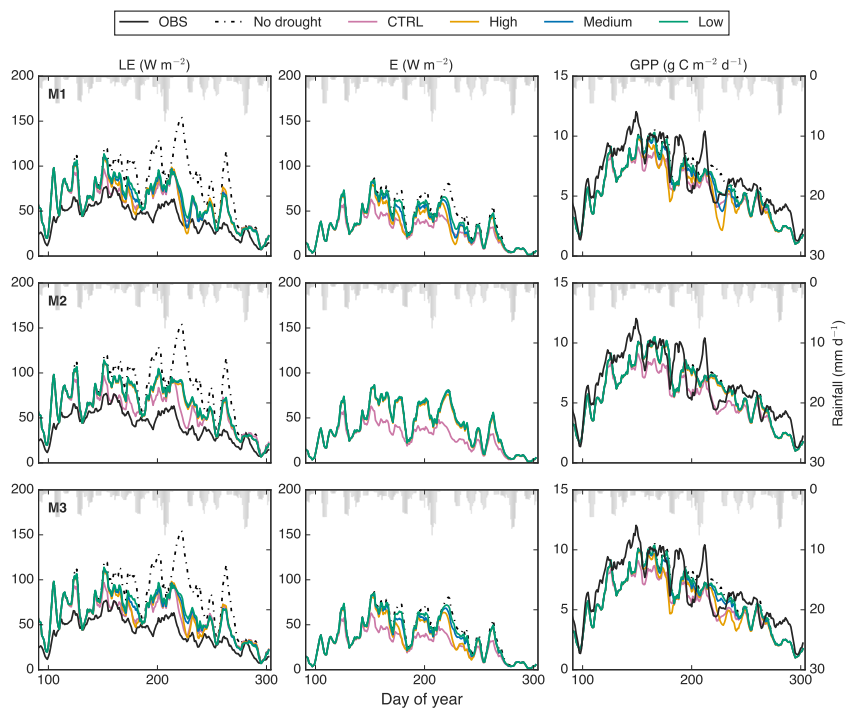

Figure 3. A comparison of the observed (OBS) and modelled latent Heat (LE), transpiration $(E)$ and gross primary productivity (GPP) at the Tharandt site during 2003. Simulations show the control (CTRL) and the three parameterisations that represent a spectrum of behaviour ranging from a high to low drought sensitivity, and the tested methods to obtain a weighted estimate of soil water potential $\left(\Psi_{\mathrm{S}}\right)$ across CABLE's soil layers (M1-M3). M1 uses a root-biomass weighted soil water content converted to $\Psi_{\mathrm{S}}$, M2 calculates $\Psi_{\mathrm{S}}$ by integrated soil water content over the top $1.7 \mathrm{~m}$ of the soil, and M3 is calculated using a dynamic weight across soil layers. The data have been smoothed with a 5-day moving window to aid visualisation and the grey bars show daily rainfall. 


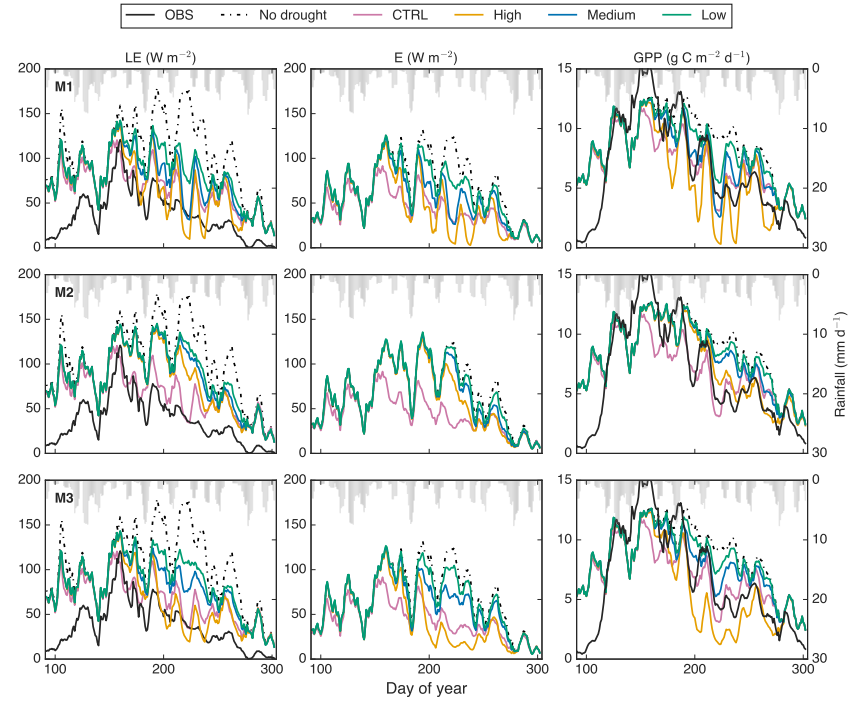

Figure 4. A comparison of the observed (OBS) and modelled latent Heat $(\mathrm{LE})$, transpiration $(E)$ and gross primary productivity (GPP) at the Hesse site during 2003. Simulations show the control (CTRL) and the three parameterisations that represent a spectrum of behaviour ranging from a high to low drought sensitivity, and the tested methods to obtain a weighted estimate of soil water potential $\left(\Psi_{\mathrm{S}}\right)$ across CABLE's soil layers (M1-M3). M1 uses a root-biomass weighted soil water content converted to $\Psi_{\mathrm{S}}$, M2 calculates $\Psi_{\mathrm{S}}$ by integrated soil water content over the top $1.7 \mathrm{~m}$ of the soil, and M3 is calculated using a dynamic weight across soil layers. The data have been smoothed with a 5-day moving window to aid visualisation and the grey bars show daily rainfall.

rapid decline in $\Psi_{\mathrm{S}}$ (owing to the non-linear relationship between $\theta$ and $\Psi_{\mathrm{S}}$, Fig. 1), which causes an unrealistically abrupt shutdown of transpiration. M2 showed a greater separation between the three sensitivity parameterisations than method one. The greater separation is most evident at the xeric sites; the model performs particularly well at Espirra $\left(\mathrm{LE}\right.$ RMSE $<16 \mathrm{~W} \mathrm{~m}^{-2}$ vs. CTRL RMSE $=35.31 \mathrm{~W} \mathrm{~m}^{-2}$ ) and to a lesser extent at Castelporziano (LE low sensitivity $\operatorname{RMSE}=19.72 \mathrm{~W} \mathrm{~m}^{-2}$ vs. CTRL RMSE $=31.76 \mathrm{~W} \mathrm{~m}^{-2}$ ) (Table 4). Nevertheless, at the two mesic sites, the model completely underestimates the size of the drought, as a result of using a large soil water bucket $(1.7 \mathrm{~m})$ to calculate $\Psi_{\mathrm{S}}$. M3 in combination with the new drought model generally performed the best across all the sites, as it allows CABLE to simulate a more gradual reduction of fluxes during drought. At Roccarespampani a medium drought sensitivity performed best at reproducing the observed LE (CTRL $\mathrm{RMSE}=38.0 \mathrm{~W} \mathrm{~m}^{-2}$ vs. $18.27 \mathrm{~W} \mathrm{~m}^{-2}$ ), whilst at Espirra $\left(\mathrm{CTRL}\right.$ RMSE $=35.31 \mathrm{~W} \mathrm{~m}^{-2}$ vs. $\left.15.40 \mathrm{~W} \mathrm{~m}^{-2}\right)$ the low sensitivity performed best (Table 4). At Castelporziano, both low $\left(\right.$ CTRL RMSE $=31.76 \mathrm{~W} \mathrm{~m}^{-2}$ vs. $\left.20.41 \mathrm{~W} \mathrm{~m}^{-2}\right)$ and medium sensitivity (LE RMSE $=20.47 \mathrm{~W} \mathrm{~m}^{-2}$ ) performed well (Table 4). In contrast, at the two mesic sites, a high drought sensitivity performed best, although at both Hesse

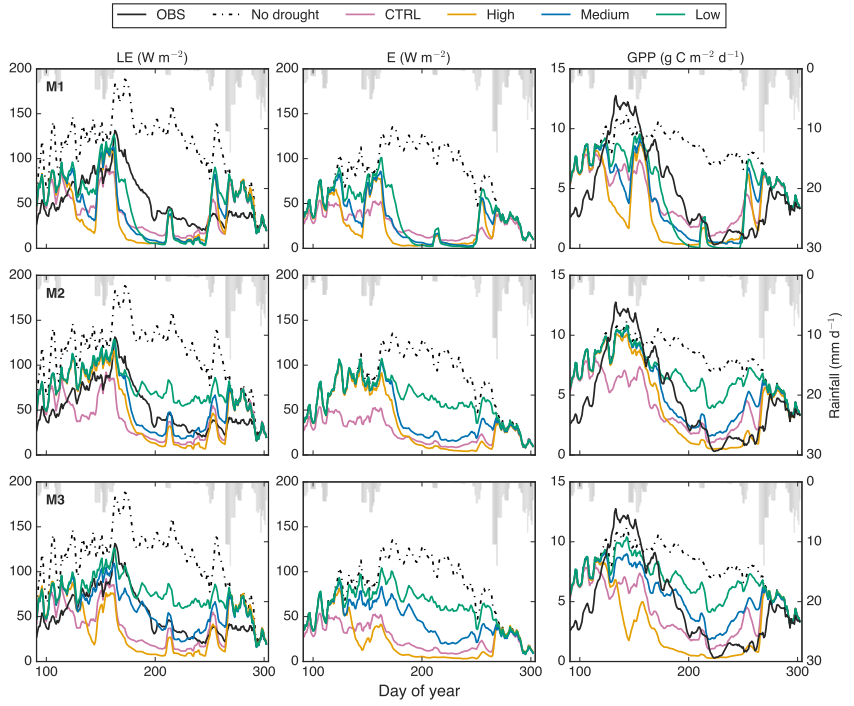

Figure 5. A comparison of the observed (OBS) and modelled latent Heat (LE), transpiration $(E)$ and gross primary productivity (GPP) at the Roccarespampani site during 2003. Simulations show the control (CTRL) and the three parameterisations that represent a spectrum of behaviour ranging from a high to low drought sensitivity, and the tested methods to obtain a weighted estimate of soil water potential $\left(\Psi_{\mathrm{S}}\right)$ across CABLE's soil layers (M1-M3). M1 uses a root-biomass weighted soil water content converted to $\Psi_{\mathrm{S}}$, M2 calculates $\Psi_{\mathrm{S}}$ by integrated soil water content over the top $1.7 \mathrm{~m}$ of the soil, and M3 is calculated using a dynamic weight across soil layers. The data have been smoothed with a 5-day moving window to aid visualisation and the grey bars show daily rainfall.

(LE CTRL RMSE $=21.25 \mathrm{~W} \mathrm{~m}^{-2}$ vs. $25.90 \mathrm{~W} \mathrm{~m}^{-2}$ ) and Tharandt (LE CTRL RMSE $=28.5 \mathrm{~W} \mathrm{~m}^{-2}$ vs. $28.82 \mathrm{~W} \mathrm{~m}^{-2}$ ), the new drought model performed marginally worse than the CTRL (Table 4).

\subsection{Impact of new drought scheme on modelled GPP}

At the more xeric sites, there were noticeable improvements in simulated GPP during the drought period (Figs. 3-7). Similar to the LE result, across all sites M3 worked best (Table 5): using a medium drought sensitivity at both Roccarespampani (CTRL $\mathrm{RMSE}=2.49 \mathrm{~g} \mathrm{C} \mathrm{m}^{-2} \mathrm{~d}^{-1} \quad$ vs. $1.73 \mathrm{~g} \mathrm{C} \mathrm{m}^{-2} \mathrm{~d}^{-1}$ ) and Castelporziano (CTRL RMSE $=2.22 \mathrm{~g} \mathrm{C} \mathrm{m}^{-2} \mathrm{~d}^{-1} \quad$ vs. $0.95 \mathrm{~g} \mathrm{C} \mathrm{m}^{-2} \mathrm{~d}^{-1}$ ), and a low sensitivity at Espirra (CTRL RMSE $=3.03 \mathrm{~g} \mathrm{C} \mathrm{m}^{-2} \mathrm{~d}^{-1}$ vs. $\left.1.43 \mathrm{~g} \mathrm{C} \mathrm{m}^{-2} \mathrm{~d}^{-1}\right)$. At the mesic end of the gradient, a medium sensitivity at Hesse $\left(\mathrm{CTRL} R M S E=2.85 \mathrm{~g} \mathrm{C} \mathrm{m}^{-2} \mathrm{~d}^{-1}\right.$ vs. $2.71 \mathrm{~g} \mathrm{C} \mathrm{m}^{-2} \mathrm{~d}^{-1}$ ) and a medium or high sensitivity at Tharandt worked best; although using either sensitivity performed slightly worse than the CTRL (CTRL RMSE $=2.06 \mathrm{~g} \mathrm{C} \mathrm{m}^{-2} \mathrm{~d}^{-1}$ vs. $>=2.23 \mathrm{~g} \mathrm{C} \mathrm{m}^{-2} \mathrm{~d}^{-1}$ ) (Table 5). 
Table 4. Summary statistics of modelled and observed latent heat (LE) at the five FLUXNET sites during the main drought period (1 June to 31 August 2003). The results of the three parameterisations, which represent a spectrum of behaviour, ranging from high to low drought sensitivity, are shown for the three tested approaches (M1-M3) to obtain a weighted estimate of soil water potential ( $\left.\Psi_{\mathrm{S}}\right)$ across CABLE's soil layers. M1 uses a root-biomass weighted soil water content converted to $\Psi_{\mathrm{S}}$, M2 calculates $\Psi_{\mathrm{S}}$ by integrated soil water content over the top $1.7 \mathrm{~m}$ of the soil, and M3 is calculated using a dynamic weighting across soil layers. Sites have been ordered to show a mesic-xeric transition between sites (Tharandt to Espirra). For each site the best performing model simulation has been highlighted in bold.

\begin{tabular}{|c|c|c|c|c|c|c|c|c|c|c|c|c|c|}
\hline \multirow[t]{2}{*}{ Site } & \multirow[t]{2}{*}{$\Psi_{\mathrm{S}}$ Method } & \multicolumn{4}{|c|}{$\begin{array}{l}\text { Root Mean Squared Error } \\
\quad\left(\text { RMSE; } \mathrm{W} \mathrm{m}^{-2} \text { ) }\right.\end{array}$} & \multicolumn{4}{|c|}{$\begin{array}{l}\text { Nash-Sutcliffe efficiency } \\
\text { (NSE) }\end{array}$} & \multicolumn{4}{|c|}{$\begin{array}{l}\text { Pearsons's correlation coefficient } \\
\qquad(r)\end{array}$} \\
\hline & & CTRL & High & Medium & Low & CTRL & High & Medium & Low & CTRL & High & Medium & Low \\
\hline \multirow{3}{*}{ Tharandt } & M1 & 21.25 & 24.64 & 26.57 & 29.55 & -0.70 & -1.28 & -1.65 & -2.28 & 0.69 & 0.73 & 0.73 & 0.70 \\
\hline & M2 & & 34.59 & 36.20 & 36.97 & & -3.50 & -3.93 & -4.14 & & 0.58 & 0.56 & 0.55 \\
\hline & M3 & & 25.90 & 29.39 & 32.26 & & -1.52 & -2.25 & -2.94 & & 0.72 & 0.67 & 0.63 \\
\hline \multirow[t]{3}{*}{ Hesse } & M1 & 28.50 & 36.22 & 41.59 & 51.49 & 0.15 & -0.37 & -0.81 & -1.77 & 0.68 & 0.66 & 0.74 & 0.79 \\
\hline & M2 & & 52.60 & 59.87 & 63.46 & & -1.89 & -2.75 & -3.21 & & 0.80 & 0.75 & 0.71 \\
\hline & M3 & & 28.82 & 45.32 & 56.46 & & 0.13 & -1.15 & -2.33 & & 0.79 & 0.84 & 0.77 \\
\hline \multirow[t]{3}{*}{ Roccarespampani } & M1 & 38.00 & 48.41 & 40.98 & 34.27 & -0.34 & -1.17 & -0.55 & -0.09 & 0.67 & 0.52 & 0.67 & 0.81 \\
\hline & M2 & & 31.62 & 22.81 & 26.81 & & 0.08 & 0.52 & 0.34 & & 0.83 & 0.84 & 0.79 \\
\hline & M3 & & 45.12 & 18.27 & 29.50 & & -0.88 & 0.69 & 0.20 & & 0.67 & 0.85 & 0.81 \\
\hline \multirow[t]{3}{*}{ Castelporziano } & M1 & 31.76 & 38.77 & 40.54 & 40.40 & -8.95 & -13.82 & -15.21 & -15.10 & 0.18 & -0.08 & 0.01 & 0.06 \\
\hline & M2 & & 31.04 & 27.19 & 19.72 & & -8.50 & -6.29 & -2.84 & & 0.47 & 0.54 & 0.57 \\
\hline & M3 & & 39.17 & 20.47 & 20.41 & & -14.40 & -3.13 & -3.11 & & -0.02 & 0.55 & 0.61 \\
\hline \multirow[t]{3}{*}{ Espirra } & M1 & 35.31 & 41.52 & 40.97 & 33.87 & -3.35 & -5.02 & -4.86 & -3.01 & 0.42 & 0.32 & 0.59 & 0.70 \\
\hline & M2 & & 15.58 & 13.82 & 13.84 & & 0.15 & 0.33 & 0.33 & & 0.77 & 0.74 & 0.73 \\
\hline & M3 & & 41.01 & 20.41 & 15.40 & & -4.81 & -0.45 & 0.17 & & 0.57 & 0.53 & 0.55 \\
\hline
\end{tabular}

Table 5. Summary statistics of modelled and flux-derived gross primary productivity (GPP) at the five FLUXNET sites during the main drought period (1 June to 31 August 2003). The results of the three parameterisations, which represent a spectrum of behaviour, ranging from high to low drought sensitivity, are shown for the three tested approaches (M1-M3) to obtain a weighted estimate of soil water potential $\left(\Psi_{\mathrm{S}}\right)$ across CABLE's soil layers. M1 uses a root-biomass weighted soil water content converted to $\Psi_{\mathrm{S}}$, M2 calculates $\Psi_{\mathrm{S}}$ by integrated soil water content over the top $1.7 \mathrm{~m}$ of the soil, and M3 is calculated using a dynamic weighting across soil layers. Sites have been ordered to show a mesic-xeric transition between sites (Tharandt to Espirra). For each site the best performing model simulation has been highlighted in bold.

\begin{tabular}{|c|c|c|c|c|c|c|c|c|c|c|c|c|c|}
\hline \multirow[t]{2}{*}{ Site } & \multirow[t]{2}{*}{$\Psi_{\mathrm{S}}$ Method } & \multicolumn{4}{|c|}{$\begin{array}{l}\text { Root Mean Squared Error } \\
\left(\text { RMSE; } \mathrm{g} \mathrm{C} \mathrm{m}^{-2} \mathrm{~d}^{-1}\right)\end{array}$} & \multicolumn{4}{|c|}{$\begin{array}{l}\text { Nash-Sutcliffe efficiency } \\
\text { (NSE) }\end{array}$} & \multicolumn{4}{|c|}{$\begin{array}{l}\text { Pearsons's correlation coefficient } \\
\qquad(r)\end{array}$} \\
\hline & & CTRL & High & Medium & Low & CTRL & High & Medium & Low & CTRL & High & Medium & Low \\
\hline \multirow{3}{*}{ Tharandt } & M1 & 2.06 & 2.27 & 2.07 & 2.10 & 0.33 & 0.19 & 0.33 & 0.31 & 0.80 & 0.71 & 0.66 & 0.61 \\
\hline & M2 & & 2.25 & 2.29 & 2.30 & & 0.20 & 0.18 & 0.17 & & 0.52 & 0.51 & 0.50 \\
\hline & M3 & & 2.23 & 2.12 & 2.20 & & 0.22 & 0.30 & 0.25 & & 0.66 & 0.59 & 0.55 \\
\hline \multirow[t]{3}{*}{ Hesse } & M1 & 2.85 & 3.57 & 2.48 & 2.94 & 0.48 & 0.18 & 0.60 & 0.44 & 0.79 & 0.78 & 0.78 & 0.71 \\
\hline & M2 & & 2.65 & 3.22 & 3.47 & & 0.55 & 0.33 & 0.22 & & 0.75 & 0.67 & 0.62 \\
\hline & M3 & & 3.51 & 2.71 & 3.24 & & 0.21 & 0.53 & 0.32 & & 0.83 & 0.75 & 0.66 \\
\hline \multirow[t]{3}{*}{ Roccarespampani } & M1 & 2.49 & 3.70 & 2.69 & 2.38 & 0.42 & -0.28 & 0.32 & 0.47 & 0.85 & 0.64 & 0.82 & 0.87 \\
\hline & M2 & & 2,12 & 1.47 & 2.84 & & 0.58 & 0.80 & 0.24 & & 0.92 & 0.91 & 0.87 \\
\hline & M3 & & 3.74 & 1.73 & 3.08 & & -0.31 & 0.72 & 0.11 & & 0.84 & 0.91 & 0.85 \\
\hline \multirow[t]{3}{*}{ Castelporziano } & M1 & 2.22 & 3.46 & 3.64 & 3.76 & -2.16 & -6.71 & -7.51 & -8.08 & 0.55 & -0.18 & 0.07 & 0.13 \\
\hline & M2 & & 2.65 & 1.84 & 1.22 & & -3.52 & -1.17 & 0.04 & & 0.63 & 0.63 & 0.81 \\
\hline & M3 & & 3.71 & 0.95 & 1.46 & & -7.82 & 0.42 & -0.37 & & 0.05 & 0.81 & 0.84 \\
\hline \multirow[t]{3}{*}{ Espirra } & M1 & 3.03 & 4.39 & 4.33 & 3.72 & -2.67 & -6.72 & -6.51 & -4.55 & 0.74 & 0.58 & 0.53 & 0.67 \\
\hline & M2 & & 1.92 & 1.46 & 1.34 & & -0.48 & 0.14 & 0.28 & & 0.80 & 0.81 & 0.81 \\
\hline & M3 & & 4.70 & 2.01 & 1.43 & & -7.84 & -0.62 & 0.18 & & 0.34 & 0.74 & 0.78 \\
\hline
\end{tabular}



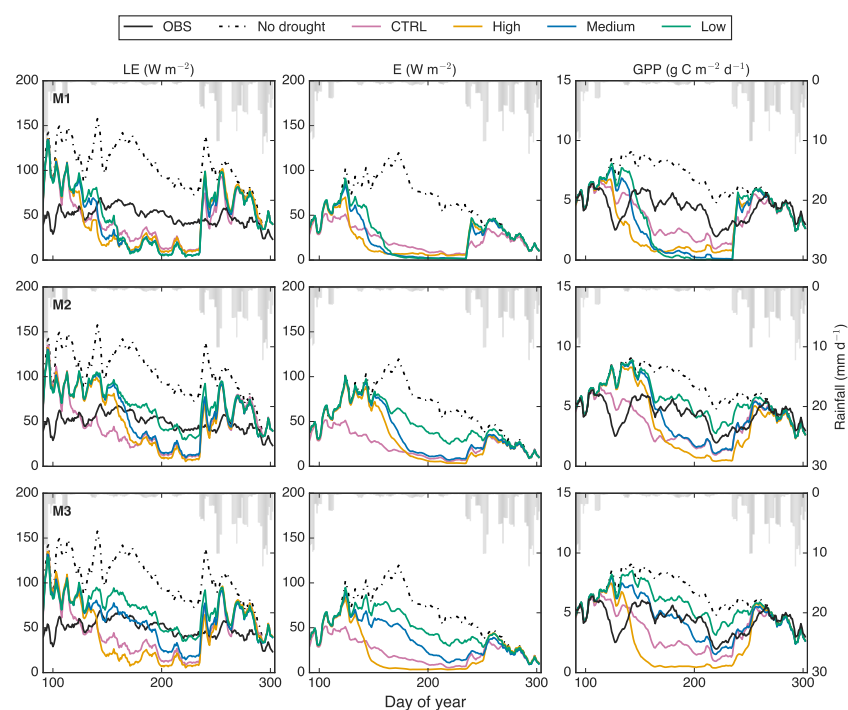

Figure 6. A comparison of the observed (OBS) and modelled latent Heat (LE), transpiration $(E)$ and gross primary productivity (GPP) at the Castelporziano site during 2003. Simulations show the control (CTRL) and the three parameterisations that represent a spectrum of behaviour ranging from a high to low drought sensitivity, and the tested methods to obtain a weighted estimate of soil water potential $\left(\Psi_{\mathrm{S}}\right)$ across CABLE's soil layers (M1-M3). M1 uses a root-biomass weighted soil water content converted to $\Psi_{\mathrm{S}}$, M2 calculates $\Psi_{\mathrm{S}}$ by integrated soil water content over the top $1.7 \mathrm{~m}$ of the soil, and M3 is calculated using a dynamic weight across soil layers. The data have been smoothed with a 5-day moving window to aid visualisation and the grey bars show daily rainfall.

\section{Discussion}

Experimental data suggest that plants exhibit a continuum of drought sensitivities, with species originating in more mesic environments showing higher sensitivity than species from more xeric environments (Bahari et al., 1985; Reich and Hinckley, 1989; Ni and Pallardy, 1991; Zhou et al., 2014). We investigated whether variable drought sensitivity improves the ability of the CABLE LSM to reproduce observed drought impacts across a latitudinal gradient. We found that, at the mesic sites, a high drought sensitivity was required; moving southwards towards more xeric sites, the sensitivity parameterisation transitioned to a medium and finally to a low drought sensitivity. Whilst this characterisation of the transition of drought sensitivities was largely consistent for both water and carbon fluxes, it is notable for the two most mesic sites, a medium rather than a high drought sensitivity performed best for carbon fluxes. There are a number of possible explanations; however, as the relationships tested are not site-specific it is hard to be conclusive as to the exact cause. Nevertheless, it does suggest that the parameterisation of the high drought sensitivity may be too sensitive at mesic sites, which will need further investigation. This work demonstrates the importance of understand-

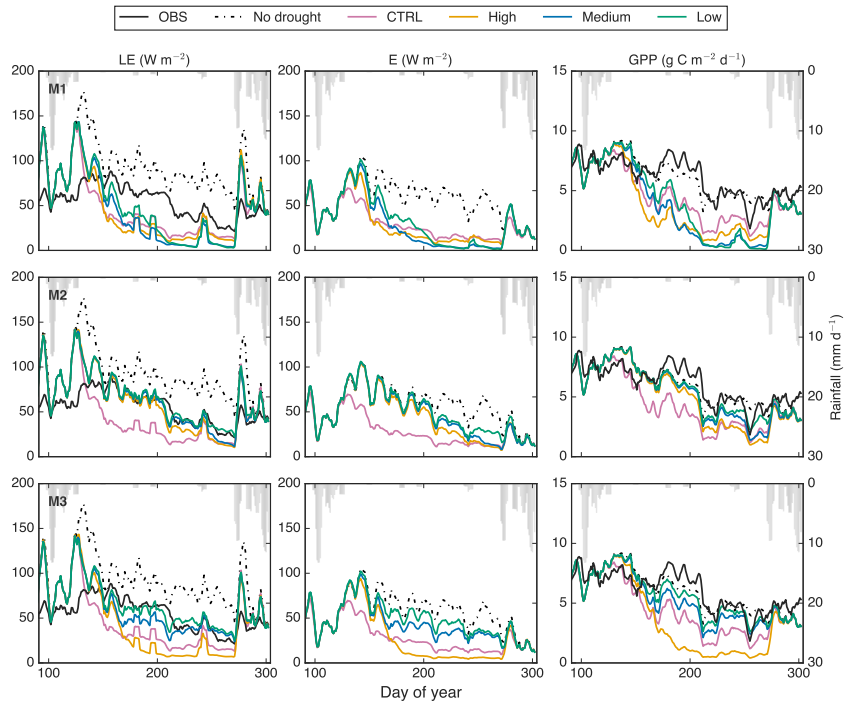

Figure 7. A comparison of the observed (OBS) and modelled latent Heat (LE), transpiration $(E)$ and gross primary productivity (GPP) at the Espirra site during 2003. Simulations show the control (CTRL) and the three parameterisations that represent a spectrum of behaviour ranging from a high to low drought sensitivity, and the tested methods to obtain a weighted estimate of soil water potential $\left(\Psi_{\mathrm{S}}\right)$ across CABLE's soil layers (M1-M3). M1 uses a root-biomass weighted soil water content converted to $\Psi_{\mathrm{S}}$, M2 calculates $\Psi_{\mathrm{S}}$ by integrated soil water content over the top $1.7 \mathrm{~m}$ of the soil, and M3 is calculated using a dynamic weight across soil layers. The data have been smoothed with a 5-day moving window to aid visualisation and the grey bars show daily rainfall.

ing how plant traits vary with climate across the landscape. However, our analysis also highlighted the importance of identifying which soil layers matter most to the plant: our results depended strongly on how we weighted soil moisture availability through the profile.

\subsection{Weighting soil moisture availability}

Commonly, empirical dependences of gas exchange on soil moisture content or potential (Eqs. 3, 4) are estimated from pot experiments (e.g. Zhou et al., 2013, 2014), in which it is fair to assume that the soil moisture content is relatively uniform and fully explored by roots. In contrast, soil moisture content and rooting depth in the field typically have strong vertical profiles. Thus, to implement such equations in a land surface model requires that we specify how to weight the soil layers to obtain a representative value of whole-profile $\theta$ or $\Psi_{\mathrm{S}}$. In this study we tested three potential implementations. Our first approach was to weight each layer by root biomass. Evidence suggests that plants preferentially access regions in the root zone where water is most freely available (Green and Clotheir, 1995; Huang et al., 1997). Hence, many models follow this approach: for example, the original version of CABLE weighted soil moisture content by root 
biomass (Eq. 2) while the Community Land Model (CLM) estimates a water stress factor based on a root-weighted $\Psi_{\mathrm{S}}$, using a PFT-defined minimum and maximum water potential (Oleson et al., 2013). However, we found that this approach performed poorly. We observed an "on-off" behaviour in response to drought, which occurs because the behaviour of the model is driven by the top soil layers, whose total soil moisture content is relatively small and root biomass is relatively high, and can be depleted rapidly, leading to a sudden onset of severe drought. Many other LSMs show this abrupt effect of drought (Egea et al., 2011; Powell et al., 2013). Powell et al. (2013) found that four models (CLM version 3.5, Integrated Biosphere Simulator version 2.6.4 (IBIS), Joint UK Land Environment Simulator version 2.1 (JULES), and Simple Biosphere model version 3 (SiB3)) implement abrupt transitions of this kind. We also found that with this weighting of soil layers, there was little effect of variable drought sensitivity: the depletion of soil moisture content of the top layers is so rapid that there is little difference between low and high sensitivities to drought. Such an outcome suggests that there is little adaptive significance of drought sensitivity, which seems unlikely. A further implication of using a root-weighted function to calculate $\Psi_{\mathrm{S}}$ is that two distinctly different scenarios, a soil that has been very wet but experienced a short dry period, allowing the topsoil to dry, and a soil that has had a prolonged period of drought but experienced a recent rainfall event, would have similar impacts on gas exchange. Again, this outcome seems unlikely.

We tested a second implementation in which soil moisture potential was calculated from the moisture content of the entire rooting zone (top five soil layers $=1.7 \mathrm{~m}$ ). Such an approach is commonly used in forest productivity models (e.g. Landsberg and Waring, 1997). However, this approach severely underestimates drought impacts because the moisture content of the total soil profile is so large, meaning that it is rarely depleted enough to impact on gas exchange.

In reality, plant water uptake shifts lower in the profile as soil dries out (e.g. Duursma et al., 2011). Thus, in our third implementation, we tested an approach in which the weighting of soil layers moves downwards as drought progresses. This approach is effectively similar to that used by the soilplant-atmosphere (SPA) model (Williams et al., 1996, 2001), in which soil layers are weighted by their soil-to-root conductance, which declines as the moisture content declines. Of the three approaches we tested, this method performed best, allowing CABLE to replicate the observations across the latitudinal mesic to xeric gradient. This dynamic weighting of $\Psi_{\mathrm{S}}$ may partially explain previous good performance by SPA in other model inter-comparisons focused on drought (e.g. Powell et al., 2013). Recently, Bonan et al. (2014) tested the suitability of using a model that considers optimal stomatal behaviour and plant hydraulics (SPA; Williams et al., 1996) for earth system modelling, and demonstrated marked improvement over the standard model during periods of drought stress. We thus suggest that models using a soil moisture stress function to simulate drought effects on gas exchange should consider a dynamic approach to weighting the contribution of different soil layers.

We note that this issue is related to another long-standing problem for LSMs: that of determining the vertical distribution of root water uptake (e.g. Feddes et al., 2001; Federer et al., 2003; Kleidon and Heimann, 1998). In the standard version of CABLE, water uptake from each soil layer initially depends on the fraction of root biomass in each layer, but moves downwards during drought as the upper layers are depleted. It is possible that changes to the weighting of soil moisture in determining drought sensitivity should also be accompanied by changes to the distribution of root water uptake, but we did not explore this option here. Li et al. (2012) previously tested an alternative dynamic root water uptake function (Lai and Katul, 2000) in CABLE, but found little improvement in predicted LE during seasonal droughts without also considering a mechanism for hydraulic redistribution. Further work should evaluate models not only against LE fluxes, but also against measurements of soil moisture profiles. Many experimental sites now routinely install multiple soil moisture sensors (e.g. direct gravimetric sampling, neutron probes, time domain reflectometry), which provide accurate insight into root water extraction and hydraulic redistribution, even down to considerable depths ( $>4 \mathrm{~m}$ ). These data have thus far been underutilised for model improvement, but should be a priority for reducing the uncertainty in soil moisture dynamics.

\subsection{Incorporating different sensitivities to drought}

Using the third and best method to calculate overall $\Psi_{\text {s }}$, we found that varying drought sensitivity across sites enabled the model to better capture drought effects across the mesic and/or xeric gradient, with a high drought sensitivity implied in mesic sites and a low drought sensitivity implied in xeric sites. These results should not be surprising, given the increasing amount of experimental evidence suggesting that drought sensitivity varies among species and across climates (e.g. Engelbrecht and Kursar, 2003; Engelbrecht et al., 2007; Skelton et al., 2015). In contrast to these data, most LSMs assume a single parameterisation for drought sensitivity, which is typically based on mesic vegetation. Our results suggest that such a parameterisation is very likely to overstate the impacts of drought on both carbon and water fluxes in drier regions.

Our work thus underlines a need to move beyond models that implement drought sensitivity through a single PFT parameterisation. Although we only compared vegetation at five sites, it has been widely shown that species originating from different hydroclimates vary in their drought sensitivities (Choat et al., 2012; Limousin et al., 2013; Zhou et al., 2014; Mitchell et al., 2014; Mencuccini et al., 2015) and our results indicate that these differing sensitivities at the plant level are also important at the ecosystem scale. It 
is, of course, challenging to implement such a continuum of sensitivities in a global vegetation model. In this study, we used a simple site-specific approach in which we selected three sets of model parameters from a meta-analysis by Zhou et al. (2013, 2014), allowing us to characterise a range of plant responses to drought. The approach we tested in this paper could not be directly implemented in global vegetation models: these models would require a more sophisticated approach that relates drought sensitivity to the climate of each pixel. One potential solution would be to develop an empirical correlation between drought sensitivity and a long-term moisture index (e.g. the ratio of mean precipitation to the equilibrium evapotranspiration; Cramer and Prentice, 1988; Gallego-Sala et al., 2010). Previous studies have demonstrated the feasibility of linking model parameters that determine plant water use strategy to such a moisture index in global simulations (Wang et al., 2014; De Kauwe et al., 2015). Such an approach would require a concerted effort to collate appropriate data, as there are few compilations to date of traits related to drought sensitivity (but see Manzoni et al., 2011; Zhou et al., 2013). Another, more challenging, alternative, would be to develop optimisation hypotheses that can predict vegetation drought sensitivity from climate (e.g. Manzoni et al., 2014).

\subsection{Further model uncertainties}

Whilst this work advances the ability of LSMs to simulate drought, it does not address all processes needed to correctly capture drought impacts. Other issues to consider include: (i) rooting depth; (ii) leaf shedding; (iii) soil evaporation; and (iv) soil heterogeneity, among others.

Here we have assumed that all sites had the soil depth $(4.6 \mathrm{~m})$, with rooting depth distributed exponentially through the profile, as is commonly used in LSMs. However, this assumption may be incorrect. Access to water by deep roots could be a potential alternative explanation for the low drought sensitivity that we inferred at the southernmost (xeric) site, Espirra. Here the dominant species is not native to the region, but rather a plantation of blue gum (Eucalyptus globulus), a species that is generally found to have high, not low, drought sensitivity (White, 1996; Mitchell et al., 2014). Many eucalypts have a deep rooting strategy (Fabião et al., 1987), suggesting a possible alternative explanation for drought tolerance at this site. More in-depth study of fluxes and soil moisture patterns at this site would be needed to determine the role of rooting depth.

During droughts, plants are often observed to shed their leaves. This is a self-regulatory mechanism to reduce water losses (Tyree et al., 1993; Jonasson et al., 1997; Bréda et al., 2006). During the 2003 heatwave at Hesse, an early reduction of approximately $1.7 \mathrm{~m}^{2} \mathrm{~m}^{-2}$ was observed. Similarly, at Brasschaat there was an observed reduction of $0.8 \mathrm{~m}^{2} \mathrm{~m}^{-2}$ and at Tharandt needle-litter was increased during September until November, with LAI estimated to be $0.9 \mathrm{~m}^{2} \mathrm{~m}^{-2}$ lower (Bréda et al., 2006; Granier et al., 2007). In contrast, models typically fix turnover rates for leaves and as such this feedback is largely absent from models. During periods of water stress, models do simulate an indirect reduction in LAI via down-regulated net primary productivity, but this feedback is much slower than is commonly observed. Not accounting for this canopy-scale feedback will result in models over-estimating carbon and water fluxes and thus losses in $\theta$ during drought.

Existing models also disagree as to the mechanism by which to down-regulate productivity during periods of water stress (De Kauwe et al., 2013). In the standard version of CABLE, only the slope of the relationship between $g_{\mathrm{s}}$ and $A$ is reduced by water stress. The SPA model behaves similarly. In contrast, JULES (Clark et al., 2011) and the Sheffield Dynamic global vegetation model (SDGVM; Woodward and Lomas, 2004), down-regulate the photosynthetic capacity via the biochemical parameters $V_{\mathrm{cmax}}$ and $J_{\max }$ (maximum electron transport rate). Here, we assumed that water stress affects both the slope of $g_{\mathrm{s}}-A$ and the biochemical parameters $V_{\text {cmax }}$ and $J_{\max }$, supported by results from Zhou et al. (2013, 2014). We did not evaluate this assumption against the eddy flux data. However, previous studies have also suggested that both effects are needed to explain responses of fluxes during drought (Keenan et al., 2010).

Finally, although models do have the capacity to simulate vertical variations in $\theta$, they do not always represent horizontal sub-grid scale variability. This assumption is likely to contribute to the abruptness of modelled transitions from well-watered to completely down-regulated carbon and water fluxes. Earlier work by Entekhabi and Eagleson (1989), and models such as the variable infiltration capacity (VIC) model (Liang et al., 1994), and most recently Decker (2015) has attempted to address this issue by employing statistical distributions to approximate horizontal spatial heterogeneity in soil moisture (see also Crow and Wood, 2002). These parsimonious approaches typically require few parameters, making them attractive in the LSM context and potentially suitable for modelling ecosystem and hydrological responses to drought (Luo et al., 2013).

\subsection{Testing models against extreme events}

In conclusion, we have used a model evaluation against flux measurements during a large-scale heatwave event to make significant progress in modelling of drought impacts. While model evaluation against data is now commonplace (Prentice et al., 2015) and has recently been extended to formal benchmarking, particularly in the land surface community (Abramowitz, 2005; Best et al., 2015), many of these benchmarking indicators are based on seasonal or annual outputs and thus miss the opportunity to examine model performance during extreme events. Model projections under future climate change require good mechanistic representations of the impacts of extreme events. However, responses to extreme 
events are rarely evaluated and there is therefore an urgent need to orient model testing to periods of extremes. To that end, precipitation manipulation experiments (e.g. Nepstad et al., 2002; Hanson et al., 2003; Pangle et al., 2012) represent a good example of a currently under-exploited avenue (but see Fisher et al., 2007; Powell et al., 2013) that could be used for model evaluation and/or benchmarking (Smith et al., 2014). However, we urge that these exercises do not focus solely on overall model performance, but also test the realism of individual model assumptions (Medlyn et al., 2015).

\section{The Supplement related to this article is available online at doi:10.5194/bg-12-7503-2015-supplement.}

Acknowledgements. This work was supported by the Australian Research Council (ARC) Linkage grant LP140100232 and the ARC Centre of Excellence for Climate System Science (CE110001028). SZ was supported by an international Macquarie University Research Excellence Scholarship. This work is also a contribution to the AXA Chair Programme in Biosphere and Climate Impacts and the Imperial College initiative on Grand Challenges in Ecosystems and the Environment. We thank CSIRO and the Bureau of Meteorology through the Centre for Australian Weather and Climate Research for their support in the use of the CABLE model. This work used eddy covariance data acquired by the FLUXNET community for the La Thuile FLUXNET release, supported by the following networks: AmeriFlux (US Department of Energy, Biological and Environmental Research, Terrestrial Carbon Program (DE-FG02-04ER63917 and DE-FG02-04ER63911)), AfriFlux, AsiaFlux, CarboAfrica, CarboEuropeIP, CarboItaly, CarboMont, ChinaFlux, Fluxnet-Canada (supported by CFCAS, NSERC, BIOCAP, Environment Canada, and NRCan), GreenGrass, KoFlux, LBA, NECC, OzFlux, TCOS-Siberia, USCCC. We acknowledge the financial support to the eddy covariance data harmonisation provided by CarboEuropeIP, FAO-GTOS-TCO, iLEAPS, Max Planck Institute for Biogeochemistry, National Science Foundation, University of Tuscia, Université Laval and Environment Canada and US Department of Energy and the database development and technical support from Berkeley Water Center, Lawrence Berkeley National Laboratory, Microsoft Research eScience, Oak Ridge National Laboratory, University of California - Berkeley, University of Virginia. All data analysis and plots were generated using the Python language and the Matplotlib plotting library (Hunter, 2007).

Edited by: P. Stoy

\section{References}

Abramowitz, G.: Towards a benchmark for land surface models, Geophys. Res. Lett., 32, L22702, doi:10.1029/2005GL024419, 2005 .
Abramowitz, G.: Towards a public, standardized, diagnostic benchmarking system for land surface models, Geosci. Model Dev., 5, 819-827, doi:10.5194/gmd-5-819-2012, 2012.

Abramowitz, G., Leuning, R., Clark, M., and Pitman, A.: Evaluating the Performance of Land Surface Models, J. Climate, 21, 54685481, 2008.

Allen, C. D., Macalady, A. K., Chenchouni, H., Bachelet, D., McDowell, N., Vennetier, M., Kitzberger, T., Rigling, A., Breshears, D. D., Hogg, E. H. (T.), Gonzalez, P., Fensham, R., Zhang, Z., Castro, J., Demidova, N., Lim, J.-H., Allard, G., Running, S. W., Semerci, A., and Cobb, N.: A global overview of drought and heat-induced tree mortality reveals emerging climate change risks for forests, Forest Ecol. Manag., 259, 660-684, 2010.

Anderegg, W. R., Kane, J. M., and Anderegg, L. D.: Consequences of widespread tree mortality triggered by drought and temperature stress, Nature Climate Change, 3, 30-36, 2013.

Bahari, Z. A., Pallardy, S. G., and Parker, W. C.: Photosynthesis, water relations, and drought adaptation in six woody species of oak-hickory forests in central Missouri, Forest Sci., 31, 557-569, 1985.

Best, M. J., Abramowitz, G., Johnson, H. R., Pitman, A. J., Balsamo, G., Boone, A., Cuntz, M., Decharme, B., Dirmeyer, P. A., Dong, J., Ek, M., Guo, Z., Haverd, V., van den Hurk, B. J. J., Nearing, G. S., Pak, B., Peters-Lidard, C., Santanello Jr., J. A., Stevens, L., and Vuichard, N.: The Plumbing of Land Surface Models: Benchmarking Model Performance, J. Hydrometeorol., 16, 1425-1442, 2015.

Bonan, G. B., Williams, M., Fisher, R. A., and Oleson, K. W.: Modeling stomatal conductance in the earth system: linking leaf water-use efficiency and water transport along the soil-plantatmosphere continuum, Geosci. Model Dev., 7, 2193-2222, doi:10.5194/gmd-7-2193-2014, 2014.

Bréda, N., Huc, R., Granier, A., and Dreyer, E.: Temperate forest trees and stands under severe drought: a review of ecophysiological responses, adaptation processes and long-term consequences, Ann. For. Sci., 63, 625-644, 2006.

Breshears, D. D., Cobb, N. S., Rich, P. M., Price, K. P., Allen, C. D., Balice, R. G., Romme, W. H., Kastens, J. H., Floyd, M. L., Belnap, J., Anderson, J. J., Myers, O. B., and Meyer, C. W.: Regional vegetation die-off in response to global-change-type drought, $\mathrm{P}$. Natl. Acad. Sci. USA, 102, 15144-15148, 2005.

Campbell, G. S.: A simple method for determining unsaturated conductivity from moisture retention data, Soil Sci., 117, 311-314, 1974.

Chaves, M. M., Maroco, J. P., and Pereira, J. S.: Understanding plant responses to drought-from genes to the whole plant, Funct. Plant Biol., 30, 239-264, 2003.

Choat, B., Jansen, S., Brodribb, T. J., Cochard, H., Delzon, S., Bhaskar, R., Bucci, S. J., Feild, T. S., Gleason, S. M., Hacke, U. G., Jacobsen, A. L., Lens, F., Maherali, H., Martinez-Vilalta, J., Mayr, S., Mencuccini, M., Mitchell, P. J., Nardini, A., Pittermann, J., Pratt, R. B., Sperry, J. S., Westoby, M., Wright, I. J., and Zanne, A. E.: Global convergence in the vulnerability of forests to drought, Nature, 491, 752-755, 2012.

Ciais, P., Reichstein, M., Viovy, N., Granier, A., Ogee, J., Allard, V., Aubinet, M., Buchmann, N., Bernhofer, C., Carrara, A., Chevallier, F., De Noblet, N., Friend, A. D., Friedlingstein, P., Grunwald, T., Heinesch, B., Keronen, P., Knohl, A., Krinner, G., Loustau, D., Manca, G., Matteucci, G., Miglietta, F., Ourcival, J. M., 
Papale, D., Pilegaard, K., Rambal, S., Seufert, G., Soussana, J. F., Sanz, M. J., Schulze, E. D., Vesala, T., and Valentini, R.: Europewide reduction in primary productivity caused by the heat and drought in 2003, Nature, 437, 529-533, 2005.

Clapp, R. B. and Hornberger, G. M.: Empirical equations for some soil hydraulic properties, Water Resour. Res., 14, 601-604, 1978.

Clark, D. B., Mercado, L. M., Sitch, S., Jones, C. D., Gedney, N., Best, M. J., Pryor, M., Rooney, G. G., Essery, R. L. H., Blyth, E., Boucher, O., Harding, R. J., Huntingford, C., and Cox, P. M.: The Joint UK Land Environment Simulator (JULES), model description - Part 2: Carbon fluxes and vegetation dynamics, Geosci. Model Dev., 4, 701-722, doi:10.5194/gmd-4-701-2011, 2011.

Comstock, J. and Mencuccini, M.: Control of stomatal conductance by leaf water potential in Hymenoclea salsola (T. \& G.), a desert subshrub, Plant Cell Environ., 21, 1029-1038, 1998.

Cowan, I. and Farquhar, G.: Stomatal function in relation to leaf metabolism and environment., in Society for Experimental Biology Symposium, Integration of Activity in the Higher Plant, edited by: Jennings, D. H., vol. 31, Cambridge University Press, Cambridge, 471-505, 1977.

Cramer, W. and Prentice, I.: Simulation of regional soil moisture deficits on a European scale, Nor. Geogr. Tidsskr. - Nor. J. Geogr., 42, 149-151, 1988.

Crow, W. T. and Wood, E. F.: Impact of soil moisture aggregation on surface energy flux prediction during SGP'97, Geophys. Res. Lett., 29, 8-1, doi:10.1029/2001GL013796, 2002.

Cruz, F. T., Pitman, A. J., and Wang, Y.-P.: Can the stomatal response to higher atmospheric carbon dioxide explain the unusual temperatures during the 2002 Murray-Darling Basin drought?, J. Geophys. Res.-Atmos., 115, doi:10.1029/2009JD012767, 2010.

Dai, A.: Increasing drought under global warming in observations and models, Nature Climate Change, 3, 52-58, 2013.

Dawson, T. E., Burgess, S. S., Tu, K. P., Oliveira, R. S., Santiago, L. S., Fisher, J. B., Simonin, K. A., and Ambrose, A. R.: Nighttime transpiration in woody plants from contrasting ecosystems, Tree Physiol., 27, 561-575, 2007.

Decker, M.: Development and evaluation of a new soil moisture and runoff parameterization for the CABLE LSM including subgrid-scale processes, J. Adv. Model Earth Sy., doi:10.1002/2015MS000507, 2015.

De Kauwe, M. G., Medlyn, B. E., Zaehle, S., Walker, A. P., Dietze, M. C., Hickler, T., Jain, A. K., Luo, Y., Parton, W. J., Prentice, I. C., Smith, B., Thornton, P. E., Wang, S., Wang, Y.-P., Waarlind, D., Weng, E., Crous, K. Y., Ellsworth, D. S., Hanson, P. J., Seok Kim, H.-S., Warren, J. M., Oren, R., and Norby, R. J.: Forest water use and water use efficiency at elevated $\mathrm{CO}_{2}$ : a model-data intercomparison at two contrasting temperate forest FACE sites, Glob. Change Biol., 19, 1759-1779, 2013.

De Kauwe, M. G., Kala, J., Lin, Y.-S., Pitman, A. J., Medlyn, B. E., Duursma, R. A., Abramowitz, G., Wang, Y.-P., and Miralles, D. G.: A test of an optimal stomatal conductance scheme within the CABLE land surface model, Geosci. Model Dev., 8, 431-452, doi:10.5194/gmd-8-431-2015, 2015.

Duursma, R. A., Barton, C. V. M., Eamus, D., Medlyn, B. E., Ellsworth, D. S., Forster, M. A., Tissue, D. T., Linder S., and McMurtrie, R. E.: Rooting depth explains $\left[\mathrm{CO}_{2}\right] \times$ drought interaction in Eucalyptus saligna, Tree Physiol., 31, 922-931, 2011.

Egea, G., Verhoef, A., and Vidale, P. L.: Towards an improved and more flexible representation of water stress in coupled photosynthesis-stomatal conductance models, Agr. Forest Meteorol., 151, 1370-1384, 2011.

Engelbrecht, B. M. J. and Kursar, T. A.: Comparative droughtresistance of seedlings of 28 species of co-occurring tropical woody plants, Oecologia, 136, 383-393, 2003.

Engelbrecht, B. M. J., Comita, L. S., Condit, R., Kursar, T. A., Tyree, M. T., Turner, B. L., and Hubbell, S. P.: Drought sensitivity shapes species distribution patterns in tropical forests, Nature, 447, 80-82, 2007.

Entekhabi, D. and Eagleson, P. S.: Land surface hydrology parameterization for atmospheric general circulation models including subgrid scale spatial variability, J. Climate, 2, 816-831, 1989.

Fabião, A., Madeira, M., and Steen, E.: Root mass in plantations of Eucalyptus globulus in Portugal in relation to soil characteristics, Arid Soil Res. Rehab., 1, 185-194, 1987.

Feddes, R. A., Hoff, H., Bruen, M., Dawson, T., de Rosnay, P., Dirmeyer, P., Jackson, R. B., Kabat, P., Kleidon, A., Lilly, A., and Pitman, A. J.: Modeling root water uptake in hydrological and climate models, B. Am. Meteorol. Soc., 82, 2797-2809, 2001.

Federer, C., Vörösmarty, C., and Fekete, B.: Sensitivity of annual evaporation to soil and root properties in two models of contrasting complexity, J. Hydrometeorol., 4, 1276-1290, 2003.

Fensham, R., Fairfax, R., and Ward, D.: Drought-induced tree death in savanna, Glob. Change Biol., 15, 380-387, 2009.

Fischer, E., Seneviratne, S., Lüthi, D., and Schär, C.: Contribution of land-atmosphere coupling to recent European summer heat waves, Geophys. Res. Lett., 34, doi:10.1029/2006GL029068, 2007.

Fisher, R. A., Williams, M., Lola da Costa, A., Malhi, Y., da Costas, R. F., Almeida, S., and Meir, P.: The response of an Eastern Amazonian rain forest to drought stress: results and modelling analyses from a throughfall exclusion experiment, Glob. Change Biol., 13, 2361-2378, 2007.

Flexas, J., Barbour, M. M., Brendel, O., Cabrera, H. M., Carriquí, M., Díaz-Espejo, A., Douthe, C., Dreyer, E., Ferrio, J. P., Gago, J., Gallé, A., Galmés, J., Kodama, N., Medrano, H., Niinemets, Ü., Peguero-Pina, J. J., Pou, A., Ribas-Carbó, M., Tomás, M., Tosens, T., and Warren, C. R.: Mesophyll diffusion conductance to $\mathrm{CO}_{2}$ : an unappreciated central player in photosynthesis, Plant Sci., 193, 70-84, 2012.

Galbraith, D., Levy, P. E., Sitch, S., Huntingford, C., Cox, P., Williams, M., and Meir, P.: Multiple mechanisms of Amazonian forest biomass losses in three dynamic global vegetation models under climate change, New Phytol., 187, 647-665, 2010.

Gallego-Sala, A., Clark, J., House, J., Orr, H., Prentice, I. C., Smith, P., Farewell, T., and Chapman, S.: Bioclimatic envelope model of climate change impacts on blanket peatland distribution in Great Britain, Clim. Res., 45, 151-162, 2010.

Garcia-Forner, N., Adams, H. D., Sevanto, S., Collins, A. D., Dickman, L. T., Hudson, P. J., Zeppel, M., Martínez-Vilalta, J., and Mcdowell, N. G.: Responses of two semiarid conifer tree species to reduced precipitation and warming reveal new perspectives for stomatal regulation, Plant Cell Environ., doi:10.1111/pce.12588, 2015.

Gardner, W. R.: Dynamic aspects of water availability to plants, Soil Sci., 89, 63-73, 1960.

Gerten, D., Luo, Y., Le Maire, G., Parton, W. J., Keough, C., Weng, E., Beier, C., Ciais, P., Cramer, W., Dukes, J. S., Hanson, P. J., Knapp, A. A. K., Linder, S., Nepstad, D., Rustad, L., and 
Sowerby, A.: Modelled effects of precipitation on ecosystem carbon and water dynamics in different climatic zones, Glob. Change Biol., 14, 2365-2379, 2008.

Granier, A., Reichstein, M., Breda, N., Janssens, I. A., Falge, E., Ciais, P., Grünwald, T., Aubinet, M., Berbigier, P., Bernhofer, C., Buchmann, N., Facini, O., Grassi, G., Heinesch, B., Ilvesniemi, H., Keronen, P., Knohl, A., Kostner, B., Lagergren, F., Lindroth, A., Longdoz, B., Loustau, D., Mateus, J., Montagnani, L., Nys, C., Moors, E., Papale, D., Peiffer, M., Pilegaard, K., Pita, G., Pumpanen, J., Rambal, S., Rebmann, C., Rodrigues, A., Seufert, G., Tenhunen, J., Vesala, I., and Wang, Q.: Evidence for soil water control on carbon and water dynamics in European forests during the extremely dry year: 2003, Agr. Forest Meteorol., 143, 123-145, 2007.

Green, S. R. and Clothier, B. E.: Root water uptake by kiwifruit vines following partial wetting of the root zone, Plant Soil, 173, 317-328, 1995.

Hanson, P. J., Huston, M. A., and Todd, D. E.: Walker branch throughfall displacement experiment, in North American Temperate Deciduous Forest Responses to Changing Precipitation Regimes, edited by: Hanson, P. J. and Wullschleger, S. D., 8-31, Springer, New York, 2003.

Huang, B., Duncan, R. R., and Carrow, R. N.: Drought-resistance mechanisms of seven warm-season turfgrasses under surface soil drying: II. Root aspects, Crop Sci., 37, 1863-1869, 1997.

Hunter, J. D.: Matplotlib: A 2D graphics environment, Comput. Sci. Amp Eng., 9, 90-95, 2007.

Jonasson, S., Medrano, H., and Flexas, J.: Variation in leaf longevity of Pistacia lentiscus and its relationship to sex and drought stress inferred from leaf $\delta^{13}$ C, Funct. Ecol., 11, 282-289, 1997.

Keenan, T., García, R., Friend, A. D., Zaehle, S., Gracia, C., and Sabate, S.: Improved understanding of drought controls on seasonal variation in Mediterranean forest canopy $\mathrm{CO}_{2}$ and water fluxes through combined in situ measurements and ecosystem modelling, Biogeosciences, 6, 1423-1444, doi:10.5194/bg6-1423-2009, 2009.

Keenan, T., Sabate, S., and Gracia, C.: The importance of mesophyll conductance in regulating forest ecosystem productivity during drought periods, Glob. Change Biol., 16, 1019-1034, 2010.

Kleidon, A. and Heimann, M.: A method of determining rooting depth from a terrestrial biosphere model and its impacts on the global water and carbon cycle, Glob. Change Biol., 4, 275-286, 1998.

Klein, T.: The variability of stomatal sensitivity to leaf water potential across tree species indicates a continuum between isohydric and anisohydric behaviours, Funct. Ecol., 28, 1313-1320, 2014.

Knyazikhin, Y., Marshak, J. V., Diner, D. J., Myneni, R. B., Verstraete, M., Pinty, B., and Gobron, N.: Estimation of vegetation canopy leaf area index and fraction of absorbed photosynthetically active radiation from atmosphere-corrected MISR data, J. Geophys. Res., 103, 32239-32257, 1998.

Knyazikhin, Y., Glassy, J., Privette, J. L., Tian, Y., Lotsch, A., Zhang, Y., Wang, Y., Morisette, J. T., Votava, P., Myneni, R. B., Neman, R. R., and Running, S. W.: MODIS Leaf Area Index (LAI) and Fraction of Photosynthetically Active Radiation Absorbed by Vegetation (FPAR) Product (MOD15) Algorithm Theoretical Basis Document, available at: http://eospso. gsfc.nasa.gov/atbd/modistables.html (last access: 17 December 2015), 1999.
Kowalczyk, E., Stevens, L., Law, R., Dix, M., Wang, Y., Harman, I., Haynes, K., Srbinovsky, J., Pak, B., and Ziehn, T.: The land surface model component of ACCESS: description and impact on the simulated surface climatology, Aust. Meteorol. Ocean. J, 63, 65-82, 2013.

Kowalczyk, E. A.,Wang, Y.-P., Wang, P., Law, R. H., and Davies, H. L.: The CSIRO Atmosphere Biosphere Land Exchange (CABLE) model for use in climate models and as an offline model, CSIRO Marine and Atmospheric Research Paper 013, CSIRO, 2006.

Lai, C. T. and Katul, G.: The dynamic role of root-water uptake in coupling potential to actual transpiration, Adv. Water Resour., 23, 427-439, 2000.

Landsberg, J. and Waring, R.: A generalised model of forest productivity using simplified concepts of radiation-use efficiency, carbon balance and partitioning, Forest Ecol. Manag., 95, 209-228, 1997.

Leuning, R.: A critical appraisal of a combined stomatalphotosynthesis model for C3 plants, Plant Cell Environ., 18, 339-355, 1995.

Lewis, S. L., Brando, P. M., Phillips, O. L., van der Heijden, G. M., and Nepstad, D.: The 2010 amazon drought, Science, 331, 554-554, 2011.

Li, L., Wang, Y.-P., Yu, Q, Pak, B., Eamus, D., Yan, J., van Gorsel, E., and Baker, I. T.: Improving the responses of the Australian community land surface model (CABLE) to seasonal drought, J. Geophys. Res-Biogeo., 117, doi:10.1029/2012JG002038, 2012.

Liang, X., Lettenmaier, D. P., Wood, E. F., and Burges, S. J.: A simple hydrologically based model of land surface water and energy fluxes for general circulation models, J. Geophys. Res.-Atmos. 99, 14-415, 1994.

Limousin, J.-M., Bickford, C. P., Dickman, L. T., Pangle, R. E., Hudson, P. J., Boutz, A. L., Gehres, N., Osuna, J. L., Pockman, W. T., and McDowell, N. G.: Regulation and acclimation of leaf gas exchange in a piñon-juniper woodland exposed to three different precipitation regimes, Plant Cell Environ., 36, 1812-1825, 2013.

Lin, Y.-S., Medlyn, B. E., Duursma, R. A., Prentice, I. C., Wang, H., Baig, S., Eamus, D., de Dios, V. R., Mitchell, P., Ellsworth, D. S., de Beeck, M. O., Wallin, G., Uddling, J., Tarvainen, L., Linderson, M.-L., Cernusak, L. A., Nippert, J. B., Ocheltree, T. W., Tissue, D. T., Martin-StPaul, N. K., Rogers, A., Warren, J. M., De Angelis, P., Hikosaka, K., Han, Q., Onoda, Y., Gimeno, T. E., Barton, C. V. M., Bennie, J., Bonal, D., Bosc, A., Low, M., Macinins-Ng, C., Rey, A., Rowland, L., Setterfield, S. A., TauszPosch, S., Zaragoza-Castells, J., Broadmeadow, M. S. J., Drake, J. E., Freeman, M., Ghannoum, O., Hutley, L. B., Kelly, J. W., Kikuzawa, K., Kolari, P., Koyama, K., Limousin, J.-M., Meir, P., Lola da Costa, A. C., Mikkelsen, T. N., Salinas, N., Sun, W., and Wingate, L.: Optimal stomatal behaviour around the world, Nature Climate Change, 5, 459-464, 2015.

Lorenz, R., Pitman, A. J., Donat, M. G., Hirsch, A. L., Kala, J., Kowalczyk, E. A., Law, R. M., and Srbinovsky, J.: Representation of climate extreme indices in the ACCESS1.3b coupled atmosphere-land surface model, Geosci. Model Dev., 7, 545567, doi:10.5194/gmd-7-545-2014, 2014.

Luo, X., Liang, X., and McCarthy, H. R.: VIC+ for water-limited conditions: a study of biological and hydrological processes and 
their interactions in the soil-plant-atmosphere continuum, Water Resour. Res., 49, 7711-7732, 2013.

Mahfouf, J.-F., Ciret, C., Ducharne, A., Irannejad, P., Noilhan, J., Shao, Y., Thornton, P., Xue, Y., and Yang, Z.-L.: Analysis of transpiration results from the RICE and PILPS workshop, Global Planet. Change, 13, 73-88, 1996.

Manzoni, S.: Integrating plant hydraulics and gas exchange along the drought-response trait spectrum, Tree Physiol, 34, 10311034, 2014.

Manzoni, S., Vico, G., Katul, G., Fay, P. A., Polley, W., Palmroth, S., and Porporato, A. Optimizing stomatal conductance for maximum carbon gain under water stress: a meta-analysis across plant functional types and climates, Funct. Ecol., 25, 456-467, 2011.

Mao, J., Pitman, A. J., Phipps, S. J., Abramowitz, G., and Wang, Y.: Global and regional coupled climate sensitivity to the parameterization of rainfall interception, Clim. Dynam., 37, 171-186, 2011.

McDowell, N., Pockman, W. T., Allen, C. D., Breshears, D. D., Cobb, N., Kolb, T., Plaut, J., Sperry, J., West, A., Williams, D. G., and Yepez, E. A.: Mechanisms of plant survival and mortality during drought: why do some plants survive while others succumb to drought?, New Phytol., 178, 719-739, 2008.

Medlyn, B. E., Duursma, R. A., Eamus, D., Ellsworth, D. S., Prentice, I. C., Barton, C. V. M., Crous, K. Y., De Angelis, P., Freeman, M. and Wingate, L.: Reconciling the optimal and empirical approaches to modelling stomatal conductance, Glob. Change Biol., 17, 2134-2144, 2011.

Medlyn, B. E., Zaehle, S., De Kauwe, M. G., Walker, A. P., Dietze, M. C., Hanson, P. J., Hickler, T., Jain, A. K., Luo, Y., Parton, W., Prentice, I. C., Thornton, P. E., Wang, S., Wang, Y.-P., Weng, E., Iversen, C. M., McCarthy, H. R., Warren, J. M., Oren, R., and Norby, R. J.: Using ecosystem experiments to improve vegetation models, Nature Climate Change, 5, 528-534, 2015.

Mencuccini, M., Minunno, F., Salmon, Y., Martínez-Vilalta, J., and Hölttä, T.: Coordination of physiological traits involved in drought-induced mortality of woody plants, New Phytol., 208, 396-409, doi:10.1111/nph.13461, 2015.

Mitchell, P., O'Grady, A., Tissue, D., Worledge, D., and Pinkard, E.: Co-ordination of growth, gas exchange and hydraulics define the carbon safety margin in tree species with contrasting drought strategies, Tree Physiol., 34, 443-458, 2014.

Mitchell, P. J., O’Grady, A. P., Tissue, D. T., White, D. A., Ottenschlaeger, M. L., and Pinkard, E. A.: Drought response strategies define the relative contributions of hydraulic dysfunction and carbohydrate depletion during tree mortality, New Phytol., 197, 862-872, 2013.

Nepstad, D. C., Moutinho, P., Dias-Filho, M. B., Davidson, E., Cardinot, G., Markewitz, D., Figueiredo, R., Vianna, N., Chambers, J., Ray, D., Guerreiros, J. B., Lefebvre, P., Sternberg, L., Moreira, M., Barros, L., Ishida, F. Y., Tohlver, I., Belk, E., Kalif, K., and Schwalbe, K.: The effects of partial throughfall exclusion on canopy processes, aboveground production, and biogeochemistry of an Amazon forest, J. Geophys. Res., 107, 2156-2202, 2002.

Nepstad, D. C., Tohver, I. M., Ray, D., Moutinho, P., and Cardinot, G.: Mortality of large trees and lianas following experimental drought in an Amazon forest, Ecology, 88, 2259-2269, 2007.
Ni, B.-R. and Pallardy, S. G.: Response of gas exchange to water stress in seedlings of woody angiosperms, Tree Physiol., 8, 1-9, 1991.

Oleson, K. W., Lawrence, D. M., Bonan, G. B., Drewniak, B., Huang, M., Koven, C. D., Levis, S., Li, F., Riley, W. J., Subin, Z. M., Swenson, S. C., Thornton, P. E., Bozbiyik, A., Fisher, R., Heald, C. L., Kluzek, E., Lamarque, J.-F., Lawrence, P. J., Leung, L. R., Lipscomb, W., Muszala, S., Ricciuto, D. M., Sacks, W., Sun, Y., Tang, J., and Yang, Z.-L.: Technical Description of version 4.5 of the Community Land Model (CLM), NCAR Technical Note, Citeseer, National Center for Atmospheric Research, P.O. Box 3000, Boulder, Colarado., 2013.

Pangle, R. E., Hill, J. P., Plaut, J. A., Yepez, E. A., Elliot, J. R., Gehres, N., McDowell, N. G., and Pockman, W. T.: Methodology and performance of a rainfall manipulation experiment in a piñon-juniper woodland, Ecosphere, 3, art28, doi:10.1890/ES11-00369.1, 2012.

Peng, C., Ma, Z., Lei, X., Zhu, Q., Chen, H., Wang, W., Liu, S., Li, W., Fang, X., and Zhou, X.: A drought-induced pervasive increase in tree mortality across Canada's boreal forests, Nature Climate Change, 1, 467-471, 2011.

Phillips, O. L., Aragão, L. E. O. C., Lewis, S. L., Fisher, J. B., Lloyd, J., López-González, G., Malhi, Y., Monteagudo, A., Peacock, J., Quesada, C. A., van der Heijden, G., Almeida, S., Amaral, I., Arroyo, L., Aymard, G., Baker, T. R., Bánki, O., Blanc, L., Bonal, D., Brando, P., Chave, J., de Oliveira, Á. C. A., Cardozo, N. D., Czimczik, C. I., Feldpausch, T. R., Freitas, M. A., Gloor, E., Higuchi, N., Jiménez, E., Lloyd, G., Meir, P., Mendoza, C., Morel, A., Neill, D. A., Nepstad, D., Patiño, S., Peñuela, M. C., Prieto, A., Ramírez, F., Schwarz, M., Silva, J., Silveira, M., Thomas, A. S., Steege, H., Stropp, J., Vásquez, R., Zelazowski, P., Dávila, E. A., Andelman, S., Andrade, A., Chao, K.-J., Erwin, T., Di Fiore, A., C., E. H., Keeling, H., Killeen, T. J., Laurance, W. F., Cruz, A. P., Pitman, N. C. A., Vargas, P. N., RamírezAngulo, H., Rudas, A., Salamão, R., Silva, N., Terborgh, J., and Torres-Lezama, A.: Drought sensitivity of the Amazon rainforest, Science, 323, 1344-1347, 2009.

Pitman, A., Avila, F., Abramowitz, G., Wang, Y., Phipps, S., and de Noblet-Ducoudré, N.: Importance of background climate in determining impact of land-cover change on regional climate, Nature Climate Change, 1, 472-475, 2011.

Powell, T. L., Galbraith, D. R., Christoffersen, B. O., Harper, A., Imbuzeiro, H. M. A., Rowland, L., Almeida, S., Brando, P. M., da Costa, A. C. L., Costa, M. H., Levine, N. M., Malhi, Y., Saleska, S. R., Sotta, E., Williams, M., Meir, P., and Moorcroft, P. R.: Confronting model predictions of carbon fluxes with measurements of Amazon forests subjected to experimental drought, New Phytol., 200, 350-365, 2013.

Prentice, I. C., Liang, X., Medlyn, B. E., and Wang, Y.-P.: Reliable, robust and realistic: the three R's of next-generation land-surface modelling, Atmos. Chem. Phys., 15, 5987-6005, doi:10.5194/acp-15-5987-2015, 2015.

Raupach, M.: Simplified expressions for vegetation roughness length and zero-plane displacement as functions of canopy height and area index, Bound.-Lay. Meteorol., 71, 211-216, 1994.

Raupach, M., Finkele, K., and Zhang, L.: SCAM (Soil-CanopyAtmosphere Model): Description and comparison with field data, Aspendale Aust., CSIRO CEM Tech. Rep., 132, 81, 1997. 
Reich, P. B. and Hinckley, T. M.: Influence of pre-dawn water potential and soil-to-leaf hydraulic conductance on maximum daily leaf diffusive conductance in two oak species, Funct. Ecol., 3, 719-126, 1989.

Reichstein, M., Ciais, P., Papale, D., Valentini, R., Running, S., Viovy, N., Cramer, W., Granier, A., Ogée, J., Allard, V., Aubinet, M., Bernhofer, C., Buchmann, N., Carrara, A., Grünwald, T., Heimann, M., Heinesch, B., Knohl, A., Kutsch, W., Loustau, D., Manca, G., Matteucci, G., Miglietta, F., Ourcival, J. M., Pilegaard, K., Pumpanen, J., Rambal, S., Schaphoff, S., Seufert, G., Soussana, J.-F., Sanz, M.-J., Vesala, T., and Zhao, M.: Reduction of ecosystem productivity and respiration during the European summer 2003 climate anomaly: a joint flux tower, remote sensing and modelling analysis, Glob. Change Biol., 13, 634-651, 2007.

Schär, C., Vidale, P. L., Lüthi, D., Frei, C., Häberli, C., Liniger, M. A., and Appenzeller, C.: The role of increasing temperature variability in European summer heatwaves, Nature, 427, 332336, 2004

Sheffield, J., Wood, E. F., and Roderick, M. L.: Little change in global drought over the past 60 years, Nature, 491, 435-438, 2012.

Sillmann, J., Kharin, V. V., Zhang, X., Zwiers, F. W., and Bronaugh, D.: Climate extremes indices in the CMIP5 multimodel ensemble: Part 1. Model evaluation in the present climate, J. Geophys. Res.-Atmos., 118, 1716-1733, 2013.

Skelton, R. P., West, A. G., and Dawson, T. E.: Predicting plant vulnerability to drought in biodiverse regions using functional traits, P. Natl. Acad. Sci. USA, 112, 5744-5749, 2015.

Smith, N. G., Rodgers, V. L., Brzostek, E. R., Kulmatiski, A., Avolio, M. L., Hoover, D. L., Koerner, S. E., Grant, K., Jentsch, A., and Fatichi, S., Niyogi, D.: Toward a better integration of biological data from precipitation manipulation experiments into Earth system models, Rev. Geophys., 52, 1944-9208, 2014.

Tardieu, F. and Simonneau, T.: Variability among species of stomatal control under fluctuating soil water status and evaporative demand: modelling isohydric and anisohydric behaviours, J. Exp. Bot., 49, 419-432, 1998.

Turner, N. C., Spurway, R. A., and Schulze, E.-D.: Comparison of Water Potentials Measured by in Situ Psychrometry and Pressure Chamber in Morphologically Different Species, Plant Physiol., 74, 316-319, 1984.

Tyree, M., Cochard, H., Cruiziat, P., Sinclair, B., and Ameglio, T.: Drought-induced leaf shedding in walnut: evidence for vulnerability segmentation, Plant Cell Environ., 16, 879-882, 1993.

van Mantgem, P. J., Stephenson, N. L., Byrne, J. C., Daniels, L. D., Franklin, J. F., Fulé, P. Z., Harmon, M. E., Larson, A. J., Smith, J. M., Taylor, A. H., and Veblen, T. T.: Widespread increase of tree mortality rates in the western United States, Science, 323, 521-524, 2009.
Verhoef, A. and Egea, G.: Modeling plant transpiration under limited soil water: Comparison of different plant and soil hydraulic parameterizations and preliminary implications for their use in land surface models, Agr. Forest Meteorol., 191, 22-32, 2014.

Wang, H., Prentice, I. C., and Davis, T. W.: Biophsyical constraints on gross primary production by the terrestrial biosphere, Biogeosciences, 11, 5987-6001, doi:10.5194/bg-11-5987-2014, 2014.

Wang, Y. P. and Leuning, R.: A two-leaf model for canopy conductance, photosynthesis and partitioning of available energy I: Model description and comparison with a multi-layered model, Agr. Forest Meteorol., 91, 89-111, 1998.

Wang, Y. P., Kowalczyk, E., Leuning, R., Abramowitz, G., Raupach, M. R., Pak, B., van Gorsel, E., and Luhar, A.: Diagnosing errors in a land surface model (CABLE) in the time and frequency domains, J. Geophys. Res.-Biogeo., 116, doi:10.1029/2010JG001385, 2011.

White, D.: Physiological responses to drought of Eucalyptus globulus and Eucalyptus nitens in plantations, $\mathrm{PhD}$ thesis, University of Tasmania, Tasmania, 1996.

Williams, M., Rastetter, E. B., Fernandes, D. N., Goulden, M. L., Wofsy, S. C., and Shaver, G. R. and: Modelling the soil-plantatmosphere continuum in a Quercus-Acer stand at Harvard Forest: the regulation of stomatal conductance by light, nitrogen and soil/plant hydraulic properties, Plant Cell Environ., 19, 911-927, 1996.

Williams, M., Bond, B., and Ryan, M.: Evaluating different soil and plant hydraulic constraints on tree function using a model and sap flow data from ponderosa pine, Plant Cell Amp Environ., 24, 679-690, 2001.

Woodward, F. I. and Lomas, M. R.: Vegetation dynamics - simulating responses to climate change, Biol. Rev., 79, 643-670, 2004.

$\mathrm{Xu}, \mathrm{L}$. and Baldocchi, D. D.: Seasonal trends in photosynthetic parameters and stomatal conductance of blue oak (Quercus douglasii) under prolonged summer drought and high temperature, Tree Physiol., 23, 865-877, 2003.

Zhou, S., Duursma, R. A., Medlyn, B. E., Kelly, J. W., and Prentice, I. C.: How should we model plant responses to drought? An analysis of stomatal and non-stomatal responses to water stress, Agr. Forest Meteorol., 182-183, 204-214, 2013.

Zhou, S., Medlyn, B., Sabaté, S., Sperlich, D., and Prentice, I. C.: Short-term water stress impacts on stomatal, mesophyll and biochemical limitations to photosynthesis differ consistently among tree species from contrasting climates, Tree Physiol., 10, 10351046, 2014. 